DOI: $10.52950 / E S .2021 \cdot 10.2 \cdot 002$

\title{
COMPARISON OF THE APPROACH OF THE CZECH NATIONAL BANK AND THE EUROPEAN CENTRAL BANK TO THE EFFECTS OF THE GLOBAL FINANCIAL CRISIS
}

\author{
ANDREA CECRDLOVA
}

\begin{abstract}
:
The latest global crisis, which fully erupted in 2008 , can have a significant impact on central banks credibility in the long run. During the last crisis, monetary authorities encountered zero interest rate levels and, as a result, started to use non-standard monetary policy instruments. The Czech National Bank decided to use a less standard instrument in November 2013, when it started to intervene on the foreign exchange market in order to keep the Czech currency at level 27 CZK / EUR. However, the European Central Bank also adopted a non-standard instrument, when chose a path of quantitative easing in 2015 in order to support the euro area economy by purchasing financial assets. The question remains whether the approach of Czech National Bank or the approach of European Central Bank in the crisis and post-crisis period was a more appropriate alternative. With the passage of time from the global financial crisis, it is already possible to compare the approaches of these two central banks and at least partially assess what approach was more appropriate under the given conditions. When comparing the central banks approaches to the crisis, the Czech National Bank was better, both in terms of the rate of interest rate cuts and the resulting inflation with regard to the choice of a non-standard monetary policy instrument. The recent financial crisis has revealed the application of moral hazard in practice, both on behalf of the European Central Bank and the Czech National Bank, which may have a significant impact on their credibility and independence in the coming years.
\end{abstract}

\section{Keywords:}

Monetary policy, Unconventional monetary instruments, Central bank, CNB, ECB, Exchange rate commitment, Quantitative Easing, Moral hazard

JEL Classification: E31, E42, E52

\section{Authors:}

ANDREA CECRDLOVA, Prague University of Economics and Business, Czech Republic, Email: Andrea.cecrdlova@vse.cz

\section{Citation:}

ANDREA CECRDLOVA (2021). Comparison of the Approach of the Czech National Bank and the European Central Bank to the Effects of the Global Financial Crisis. International Journal of Economic Sciences, Vol. X(2), pp. 18-46., 10.52950/ES.2021.10.2.002 


\section{Introduction}

The monetary policy of central banks (CBs) was tested in 2007-2008. The inability of US subprime borrowers ${ }^{1}$ to repay their mortgages, the securitization of these mortgages and their sale in $\mathrm{MBS}^{2}$ and $\mathrm{CDO}^{3}$ instruments (illiquid and opaque) ${ }^{4}$ to institutional investors around the world led to 2007 threat to the very core of the global financial system - the interbank financial market. In the following years the global financial and economic crisis erupted, and economic policymakers had to cope with poor performance, mainly due to a sharp decline in aggregate demand and the threat of deflation.

\section{Monetary Policy Development in the Eurozone and the CZE in the Period 2007-2019}

CBs usually use several currency instruments to calm the financial market. They can lower and raise key interest rates and provide or withdraw liquidity as needed. Both of these basic monetary policy instruments have been widely used, usually to provide liquidity, since the onset of the global financial crisis. In the early stages of the crisis, extraordinary liquidity was supplied to the market and key interest rates were reduced in a coordinated manner to zero. At the moment when interest rates reached technical zero, standard monetary policy instruments were replaced by unconventional instruments in an effort to effectively influence financial market segments.

\subsection{CNB and Monetary Easing}

The Czech National Bank (CNB) as one of the first CBs in the world started easing monetary policy in response to the outbreaking crisis. It was beginning to gradually lower its interest rates in August 2008 (see Chart 1 below).

\section{Chart 1: Development of the CNB's Key Interest Rates and HICP in 2007-2019}

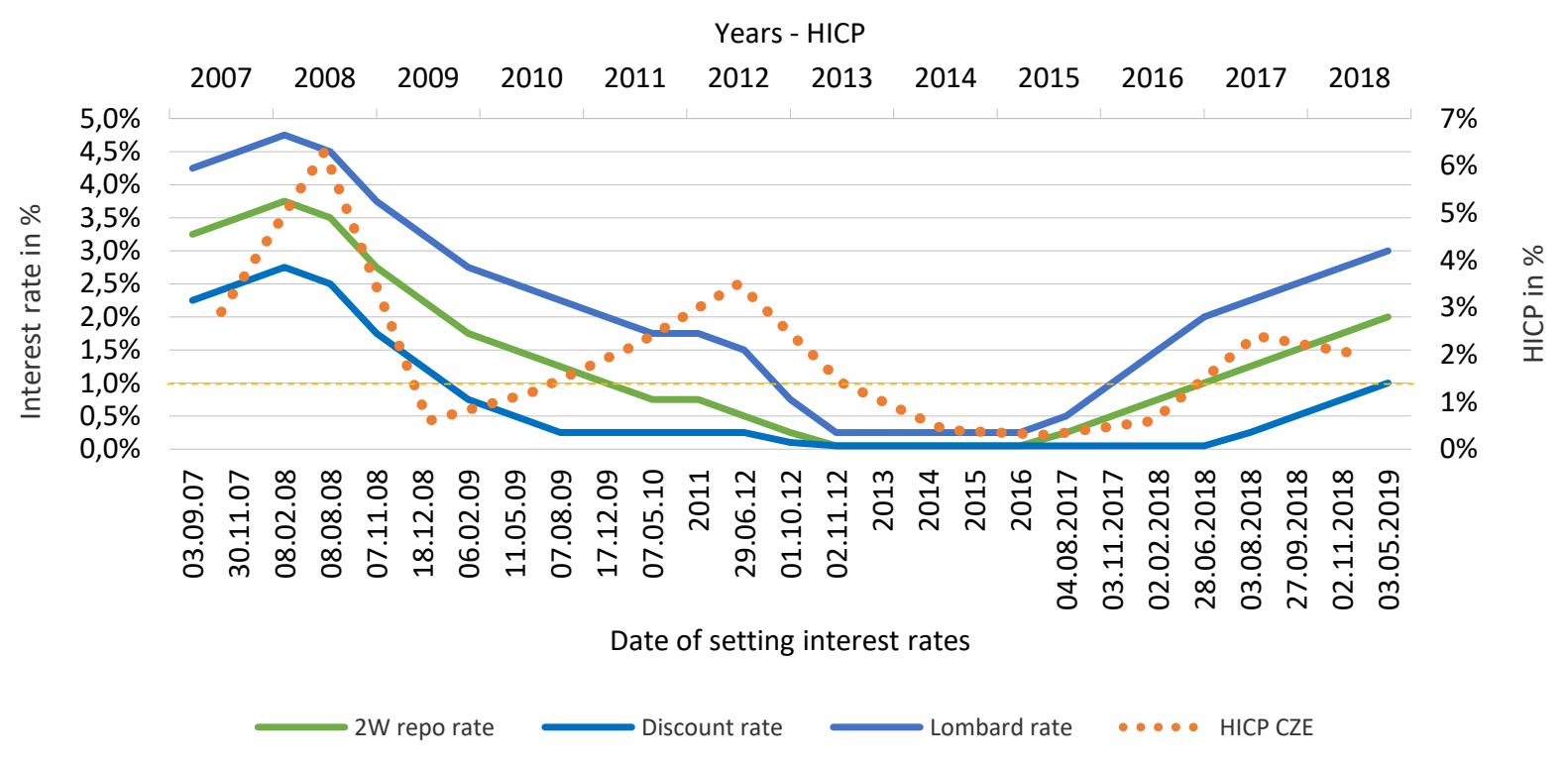

Source: CNB (2021c), EUROSTAT (2021b). Own processing

\footnotetext{
${ }^{1}$ Commercial banks were reducing interest rates on mortgage loans, especially in so-called subprime mortgages, where the interest rate is variable with the possibility of repaying only interest in the first years. These mortgages had the greatest expansion among the minority population (African Americans, Latin Americans). Source: INVESTOPEDIA. Subprime Loan Definition [online].

2 Mortgage-backed securities

${ }^{3}$ Collateralized debt obligation

${ }^{4}$ The securities were secured by mortgaged estates with unreal value.
} 
Chart 1 above shows the development of key interest rates, which the CNB used as a basic monetary policy instrument in the period 2005-2013. The CNB was lowering its rates for the vast majority of years. Their increase was evident only in the period from the second quarter of 2005 to the beginning of 2008 in order to dampen inflation growth. The advantage of the Czech economy turned out to be the floating exchange rate of Czech Crown. It weakened in response to the crisis, thus helping the economy to cope better with falling demand and falling prices. Despite some problems, the financial system remained stable and interest rate transmission somewhat weakened and slowed - remained operational.

However, the easing of monetary policy and the weakening of the exchange rate failed to prevent a slump in economic activity and rising unemployment in the following year and only a gradual improvement of the situation in the period ahead (see Chart 2 below).

\section{Chart 2: Development of Real GDP Growth in 2007-2019}

( $\%$ change compared to the previous year, annually in \%)

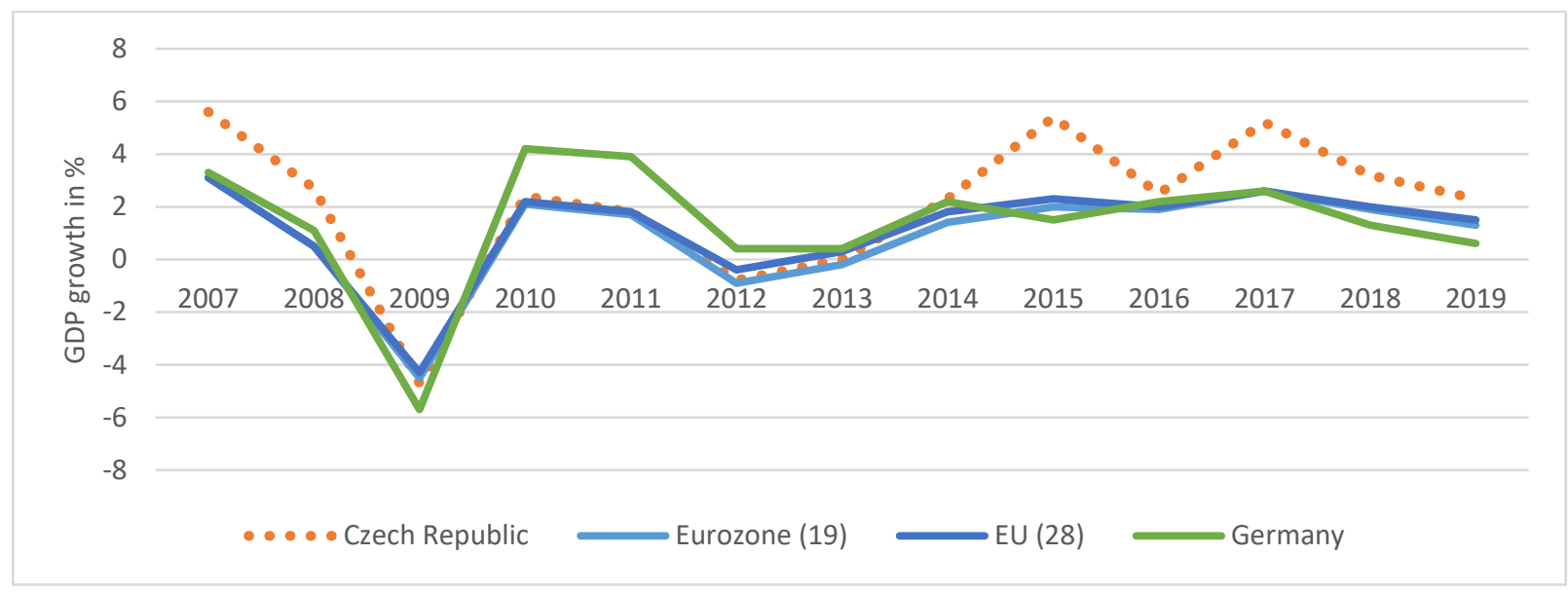

Source: EUROSTAT (2021c). Own processing

As a result of the global crisis, the growth of the Czech economy slowed down significantly in 2008, and the following year it collapsed by more than $4 \%$ (see Chart 2 above). This phenomenon was typical for the development of the entire EU, including the largest trading partner Germany. There was a gradual recovery of economies during 2010-2011, which began to weaken again in the next following 2 years. Nevertheless, it has been possible to observe gradual growth since 2013 with a few exceptions. 
Chart 3: Development of Wages and Unemployment in the Czech Republic in 2007-2019 (unemployment - \%, average; wage - \%, y/y)

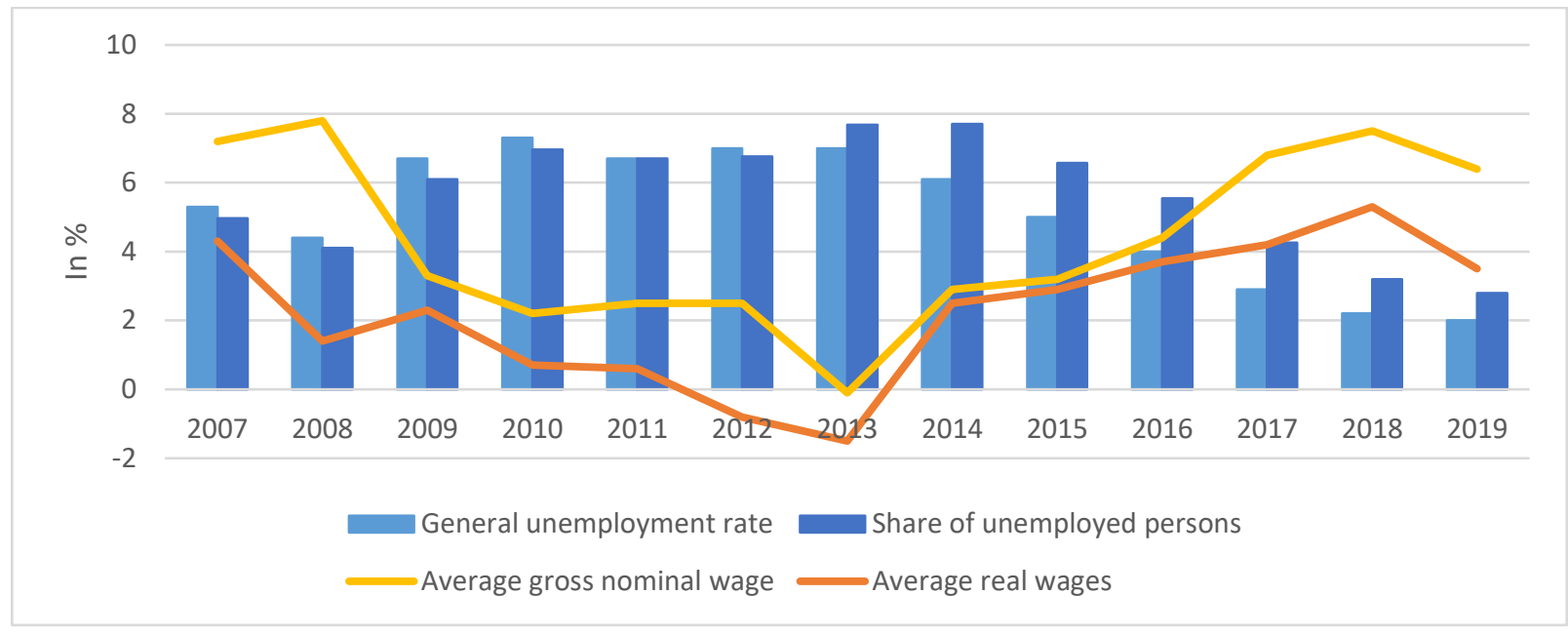

Source: CZSO (2021b). Own processing

The mentioned decline as a result of the global crisis has led to an unfavourable rise in unemployment, a fall in income, and therefore in household consumption, corporate profits and investments (see Chart 3 above). The decline in wages was reflected on the demand side, which is significantly more difficult situation for monetary policy. Thus, monetary policy could have not been effective or could only had a partial impact in the context of economic recovery.

Since 2 November 2012, key interest rates have reached a zero floor (see Chart 1 above), thus losing the ability to influence upward inflation. In November 2013, the CNB made temporary use of the exchange rate as a monetary policy instrument. The CNB undertook to prevent the Czech koruna from strengthening too much below 27 CZK/EUR through foreign exchange interventions (CNB, 2021c).

The exchange rate commitment was abandoned in April 2017 after the conditions for the sustainable fulfilment of the $2 \%$ inflation target were met. The Czech koruna remained stable even after the exit from the exchange rate commitment, when it strengthened only slightly against the euro. Subsequently, on 3 November 2017, interest rates increased (2W repo rates and Lombard rates), which thus rebounded from the zero lower limit.

\subsection{The ECB and Systemic Problems}

The global financial crisis has accelerated the emergence of serious systemic problems in the European Union (EU), especially the euro area. The European Monetary Union was created with the assumption that the introduction of the single currency will lead to the convergence of member economies. The single currency, as another stage of European integration, was thus intended to bring advantages which outweigh the disadvantages associated with its introduction.

However, the euro area, as a monetary union, is a very heterogeneous and diverse "ecosystem" due to the diversity of individual member states. One monetary policy for all countries does not necessarily suit all Member States. The uniform interest rate may thus encourage the overheating of some peripheral economies and slower growth in more developed countries.

The infallible bond markets of the euro area member states believed in unrestricted growth, and that the creditworthiness of Greece, Spain, Italy and other southern countries would match the quality of the countries of Central and Northern Europe - Germany, the Netherlands or Finland (Toman, 2012). This belief started the boom in bank lending during 2001-2007. Stock markets grew as fast as real estate ones.

In August 2009, no one was aware of the scale of Greece's budget problems. In November 2009, the Greek government acknowledged that its finances were significantly worse than 
official data. This state of public finances can be considered as the result of social policy, the credit bubble and the impossibility of devaluing the currency (Freixas, Martin, 2009). In addition to the economic crisis, in the EU has also emerged a debt crisis due to the inability of states to repay their gradually accumulated debts.

The European Central Bank (ECB) responded to the unfavourable economic and financial developments with a series of key interest rates cuts and the receipt of a significant amount of assets as collateral for refinancing operations. In the fourth quarter of 2008 the ECB cut its key interest rate by a total of 1.25 pp to $2.50 \%$, together with G10 banks in a coordinated monetary easing (see Chart 4 below). The first cut of ECB rates by $0.50 \mathrm{pp}$ in mid-October was communicated against the background of a largely stable price outlook and the currently declining inflation rate. Nonetheless, the global financial crisis brought a deeper slowdown in demand in the euro area and in the global economy than originally expected, and the ECB responded to a sharp slowdown in economic activity in the same year by cutting rates sharply again by $0.5 \mathrm{pp}$ in November and by a further $0.75 \mathrm{pp}$ in December.

\section{Chart 4: Development of ECBs' key interest rates and HICP in the Eurozone in 2007-2019}

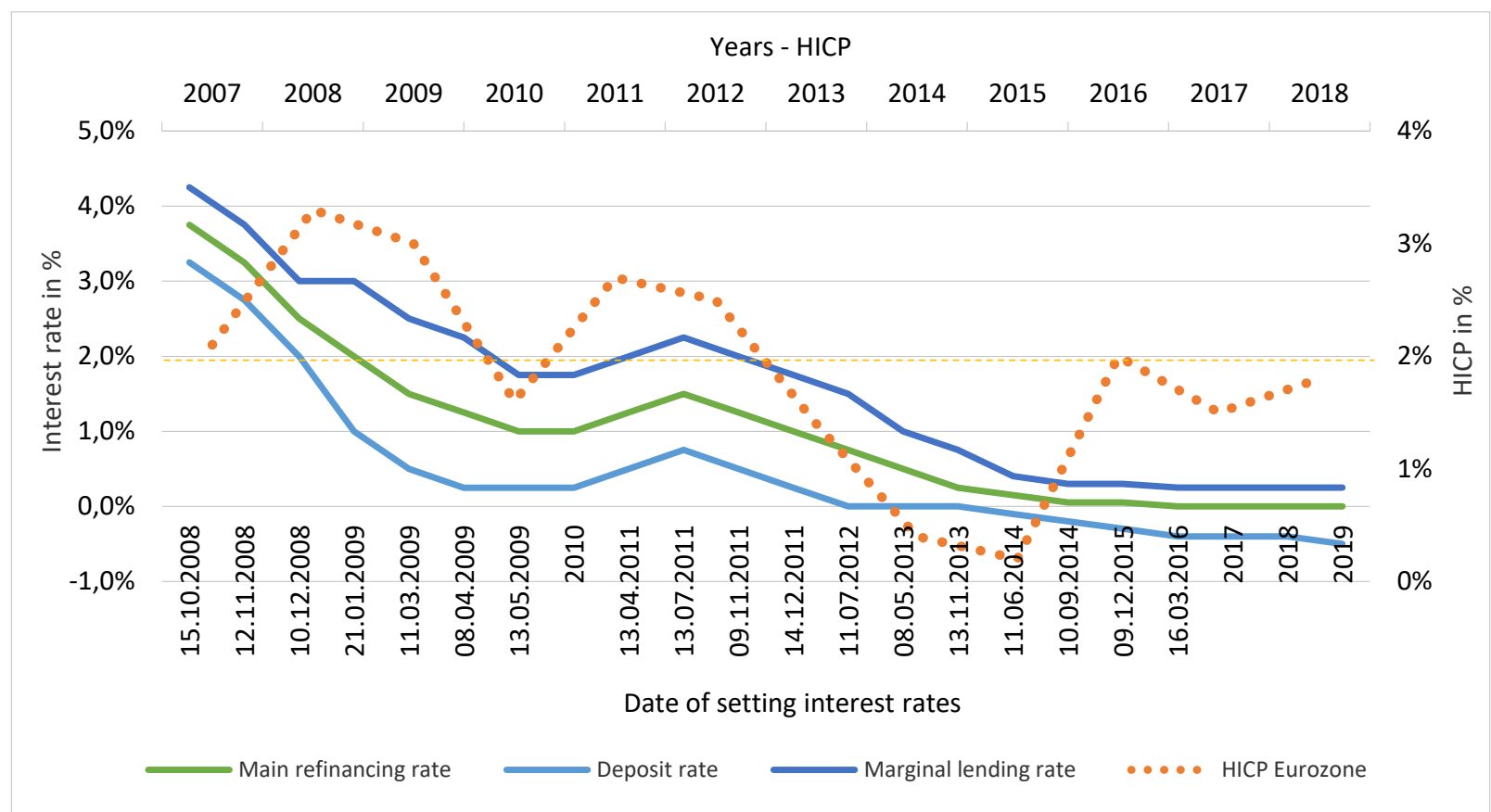

Source: ECB (2021b). EUROSTAT (2021b). Own processing

The ECB reduced its main refinancing interest rate also in the following years when it reached zero in March 2016. The exception was the first half of 2011, when interest rates rose by $0.5 \mathrm{pp}$ The ECB's decision was based on the economic recovery that prevailed in the euro area at the beginning of the year, supported by global growth and strengthening domestic demand. At the same time, headline inflation rose sharply in early 2011 (see Chart 4 above) and, according to the economic analysis, upside risks began to prevail among the risks to future inflation. The pace of money supply growth was gradually recovering, with monetary liquidity sufficient to keep inflationary pressures in the euro area under control (ECB, 2011).

As Jens Weidmann pointed out, one of the side effects of ultra-accommodative monetary policy is a reduction in profitability in the banking sector, and thus a slowdown in the creation of additional capital, which creates risks of maintaining financial stability and may ultimately limit the effectiveness of monetary policy. Banks that do not have capital reserves cannot issue any new loans. Banks need to rethink their business models, use new sources of revenue, and reduce costs. Therefore, in 2016, the President of Budesbank warned that monetary authorities must not be blind to these effects on the transmission monetary mechanism (Weidmann, 2016). 
Since the beginning of the weakening of credit markets (August 2007), the ECB has implemented measures aimed at providing liquidity to the banking sector to stabilize it through refinancing operations. Furthermore, the ECB adjusted the set instruments in the sense of extending the acceptable collateral. The Governing Council initially announced a total of 3 bond purchase programs. Under these programs, euro area national CBs were able to purchase covered bonds directly from counterparties or to intervene in euro area public debt markets to mitigate the risk of a long period of low inflation in the medium term (Hausken, 2013). The target nominal value of the covered bonds purchased was set at EUR 60 billion and later increased by a further EUR 40 billion, ie with a total volume of EUR 100 billion (CNB, 2009).

Quantitative easing (QE) is usually discussed with the advent of the penultimate securities purchase program (PSPP), which was launched on 9 March 2015 with the aim of significantly strengthening the so-called quantitative easing policy. It consisted of securities purchases on the secondary market (ECB, 2021a). The program originally envisaged monthly asset purchases of EUR 60 billion. The program did not have a fixed duration, but the ECB's original intention was to implement it by the end of August 2016, ie for 19 months (The Governing Council of the ECB, 2015). The total potential for purchases of securities under quantitative easing was thus originally set at EUR 1.140 billion.

On 18 April 2016, the ECB meeting decided to increase the monthly purchase of assets by EUR 20 billion per month, ie to a total of EUR 80 billion. The decision was made in line with the Governing Council's mandate to ensure price stability through the PSPP program and to keep inflation close to below $2 \%$ in the medium term (The Governing Council of the ECB, 2016). In the period from 9 March 2015 to 19 December 2018, the ECB thus made net purchases of public sector securities under the PSPP program in a total amount of over EUR 2 trillion (ECB, 2021a). Since January 2019, the Eurosystem no longer makes net purchases, but continues to reinvest major payments (interest) on securities held in the PSPP portfolio.

Securities purchased under the PSPP program include nominal and central government bonds with an impact on inflation; bonds issued by recognized agencies, regional and local governments, international organizations, and multilateral development banks based in the euro area. Since December 2018, government bonds and bonds of recognized agencies account for around $90 \%$ of the Eurosystem's total portfolio, while securities issued by international organizations and multilateral development banks account for around $10 \%$. On average, these shares should be maintained during the reinvestment phase (ECB, 2021a).

\section{Impact of Crisis Measures on CBs' Balance of Payments}

Following the outbreak of the global financial crisis, the CBs of the major economies adopted a few new measures with a major impact on monetary and financial conditions. These measures went far beyond the pre-crisis standard way of functioning of monetary authorities - the use of the basic monetary policy instrument of interest rates and their influencing in a positive range.

\subsection{The CNB and the Exchange Rate Commitment Regarding the Amount of Foreign Exchange Reserves}

The CNB holds a large amount of foreign exchange reserves (DR) in major world currencies, which is mainly due to the exchange rate commitment. On the other hand, it holds a relatively small amount of gold, which it largely disposed of in 1997-1998 (of the 56 tonnes of gold it owned, the CNB had only 14 tonnes left). Gold volumes have been steadily declining in recent years; at the end of 2019, the CNB already owned only 8 tonnes of gold (of which it held 7.4 tonnes for a long time, the rest it held for operational purposes) (CNB, 2019b). As can be seen from Chart 5 below, the volume of gold managed by the CNB is insignificant to other balance sheet items, in particular external claims, including securities. The volume of this item has been growing over the last 7 years, mainly due to the CNB's foreign exchange interventions. 
Chart 5: Main Items of the CNB's Balance Sheet on the Assets Aide in CZK Millions

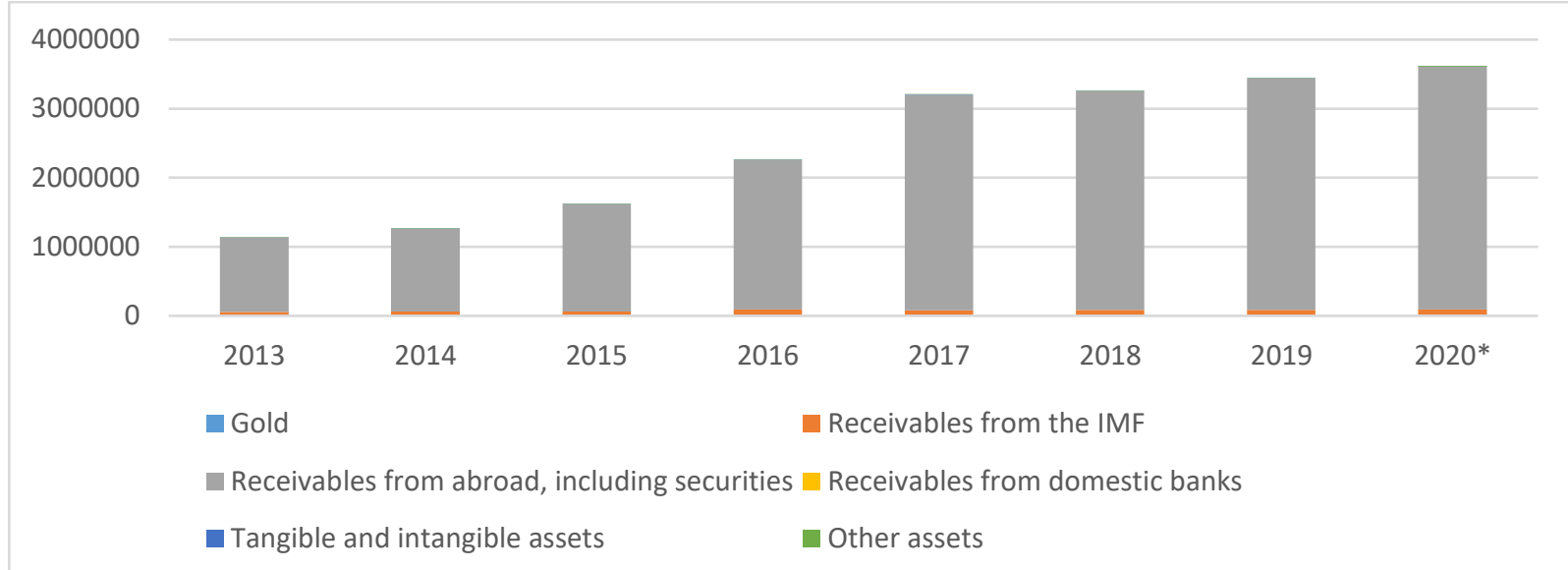

Source: CNB (2013, 2015a, 2017b, 2019b, 2021a). Own processing

The price of gold had reached an all-time high in August 2020, when it first exceeded USD 2,000 per troy ounce, yet the CNB did not plan to increase its gold reserves (Trading view, 2021). It wants to keep the minimum amount it needs for minting coins so that the stock does not fall to zero, and for a possible entry into the eurozone, as stated by the Governor of the Central Bank Jiři Rusnok (CNB, 2020a). However, if the CNB is currently presenting that higher exchange reserves may come in handy in the future and are never detrimental, as has been shown in the case of transformation, in really bad times it can be expected that the only recognized commodity will be gold, whose reserves are slowly but surely approaching zero in the case of the CNB. It is therefore not surprising that most CBs have been trying to accumulate precious metal reserves since 2010 .

The increase in exchange reserves also results in a several-fold increase in the amount of money that the Czech economy currently manages, and, as a result, in the money that commercial banks deposit with CB (see Chart 6 below - liabilities to domestic banks). However, the CNB will subsequently have to pay interest on these deposits. With the tightening of monetary policy, the CB can be expected to have to pay commercial banks higher interest rates on their money, which may put them at risk of large losses. 
Chart 6: Main Items of the CNB's Balance Sheet for the Liabilities Side in CZK Millions

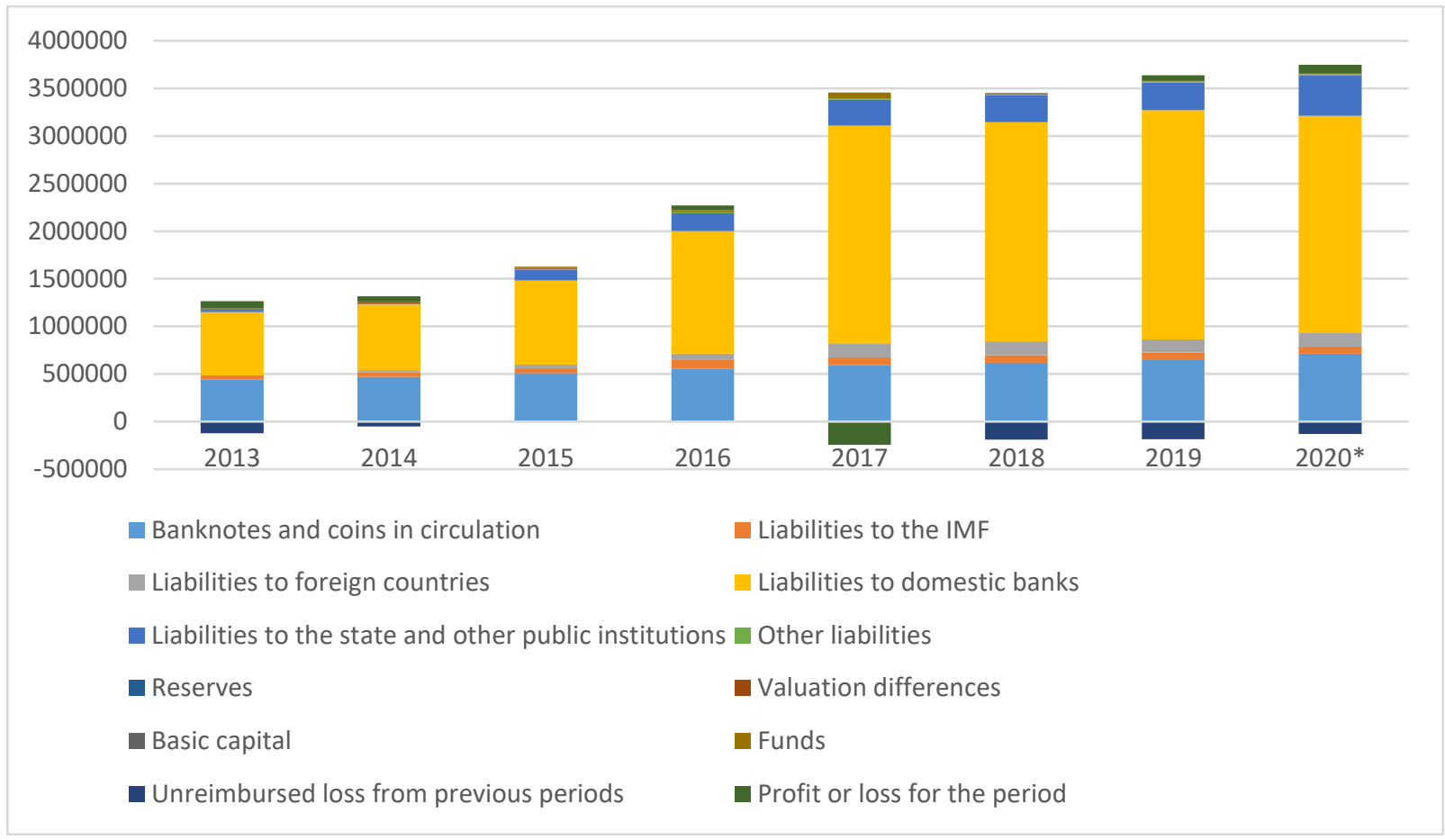

Source: CNB (2013, 2015a, 2017b, 2019b, 2021a). Own processing

The basic rule for assessing the adequacy of exchange reserves is the so-called GuidottiGreenspan rule. According to it exchange reserves should be equal to the country's short-term foreign liabilities, as this indicator reflects the country's ability to service its own short-term debt (up to 1 year) if external financing conditions are worsening (Sedláček, 2010).

In this sense, the Czech exchange reserves significantly exceeds the requirements of the above-mentioned rule. While just before the exit from the exchange rate commitment, in March 2017, the Czech koruna equivalent of the total short-term external debt of the Czech Republic was CZK 1,217 billion, as of the same date, exchange reserves represented a value of approximately CZK 3,323 billion, which is almost three times (see Chart 7 below) (CNB, 2017a). In the third quarter of 2020, the deficit of the Czech Republic's investment position abroad even decreased to CZK 655.4 billion, while the value of exchange reserves was CZK 3,657 billion (CNB, 2020b, 2021b). Currently, the CNB exceeds the requirement of the Guidotti-Greenspan's rule by more than five times.

\section{Chart 7: Development of the CNB's foreign exchange reserves in CZK millions}

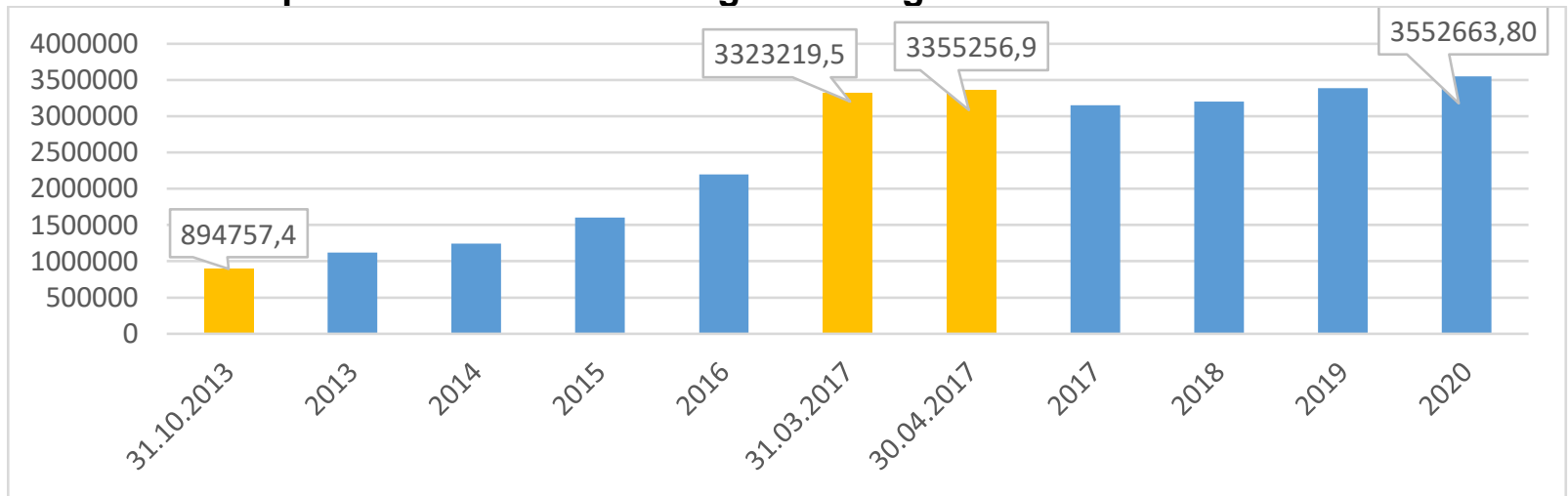

Source: CNB (2021b). Own processing

It should be noted that if the Czech Republic decided to switch to the euro, it would have to exchange all its liabilities for the euro on a one-off basis, at a rate that it would not be able to 
affect, as the value of the Eurozone entry rate is determined by the European Commission ECB. If the Czech Republic had to deal with almost $30 \%$ currency appreciation, as was the case in Slovakia, it would currently mean a loss of several trillion crowns for the Czech Republic (NBS, 2017). Otherwise, if the rule is followed, the appreciation of the Czech koruna would lead to one-fifth losses.

The volume of exchange reserves has almost quadrupled since the beginning of foreign exchange interventions (3.97 times higher), reaching CZK 3,552.7 billion at the end of 2020. In the period of maintaining a fixed exchange rate, the CNB intervened in a total volume of approximately CZK 2.46 trillion. The Czech Republic has some of the highest exchange reserves in the world in relation to its GDP. In April 2017, exchange reserves reached peaks and climbed to $70 \%$ of GDP in 2016 (CZSO, 2021b). This puts the Czech Republic at the forefront of the amount of exchange reserves in developed countries. The CNB currently has foreign exchange reserves of $65 \%$ of GDP, see Chart 8 below.

\section{Chart 8: Development of the Czech Republic's foreign exchange reserves relative to the Czech Republic's GDP in CZK millions}

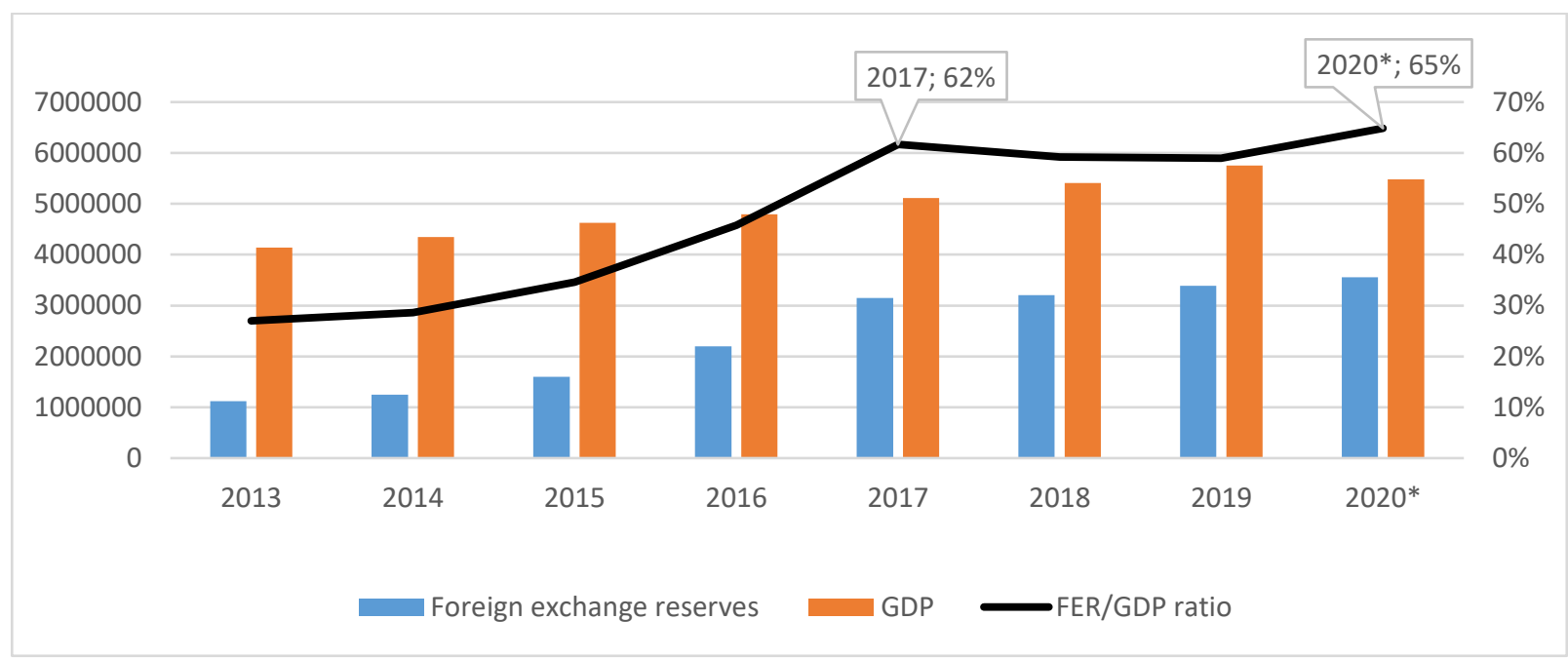

* GDP is only an estimate, based on a year-on-year decline of 4.7\% in 2020 Q4 according to CZSO data

Source: CZSO (2021a), CNB (2021b). Own processing

The adequacy of exchange reserves can also be analysed by relating their volume to the monthly volume of imports, which gives the number of months that exchange reserves should be able to finance imports. The exchange reserves should be equal to 3-4 times the monthly imports (Green, Torgerson, 2007). 


\section{Chart 9: Development of Czech imports in millions of CZK compared to foreign exchange reserves in millions of $\mathrm{CZK}$}

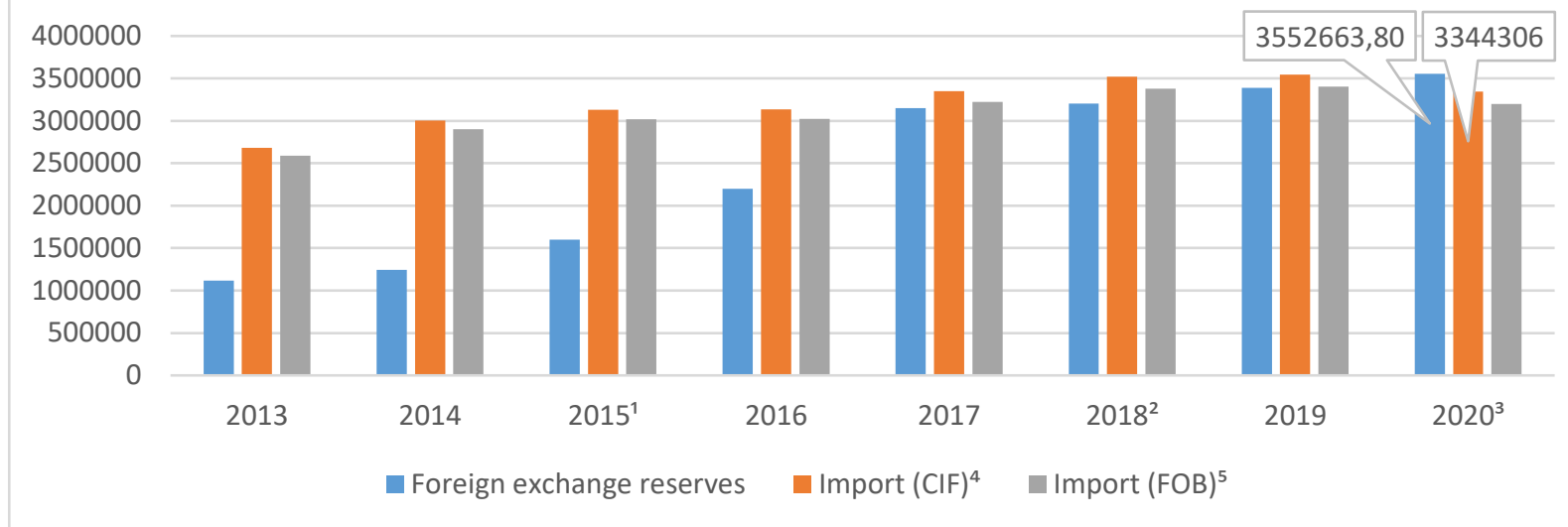

1 Imports do not include the lease of Jas-Gripen fighters in the amount of CZK 9.9 billion.

2 Data for 2018 include the import of aircraft for operating leases in the amount of CZK 10.4 billion.

3 Preliminary data.

4 Own value of goods and foreign direct trade costs associated with transport to the Czech border. Since 2016, the foreign trade methodology for capturing natural gas imports has been updated. The data do not take into account the impact in 2014 (estimated value of CZK 4.4 billion) and 2015 (estimated value of CZK 16.2 billion).

5 Value of the goods themselves not including direct commercial costs related to transport from the frontier of the country of dispatch.

Source: CZSO (2021c), CNB (2021b). Own processing

The volume of imports in March 2017 amounted to CZK 310 billion, which in terms of the above calculation is less than 11 months (CZSO, 2017b). Currently, the volume of exchange reserves has increased by approximately CZK 229 billion compared to March 2017. Given the volume of imports at the end of 2020, which averaged CZK 279 billion per month, it can also be judged from this recommendation that exchange reserves are significantly oversized (see Chart 9 above).

\section{Chart 10: Development of the CZK/EUR exchange rate}

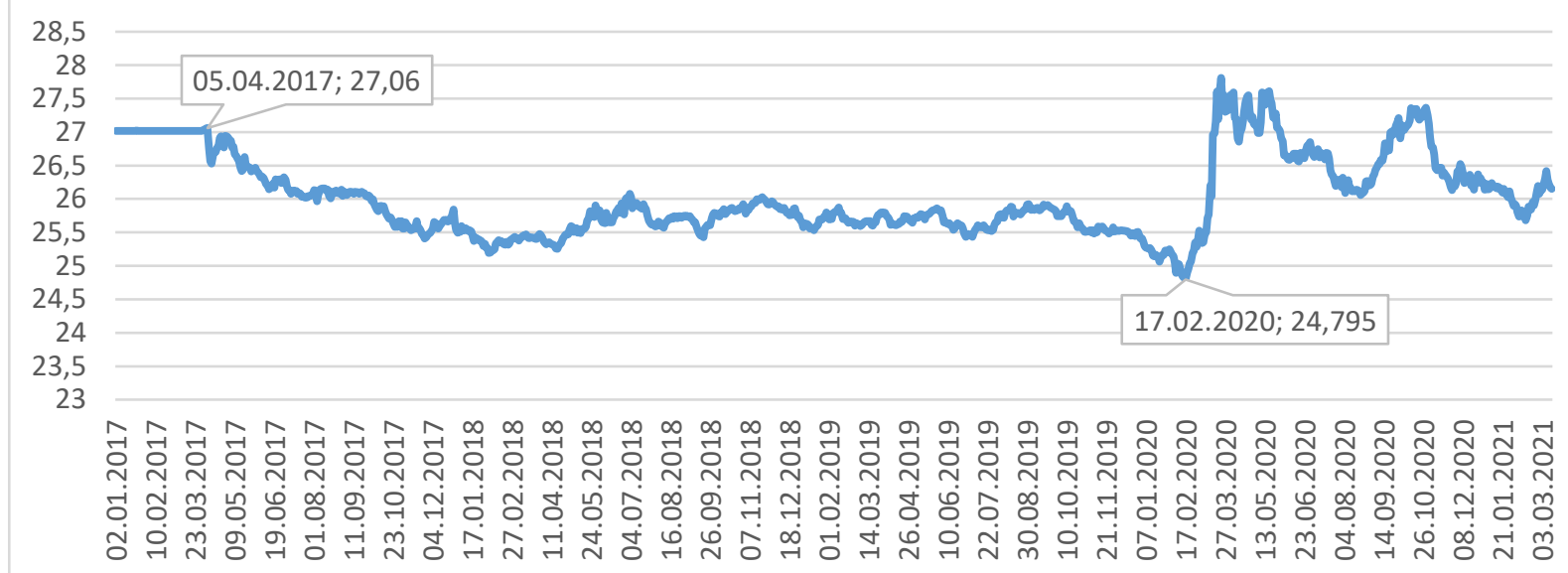

Source: CNB (2021d). Own processing

As a result of foreign exchange interventions, the CNB opened a foreign exchange position and accepted strong exchange rate risk. During the intervention, the euro was bought at a rate higher than 27 CZK / EUR. Already at the exit from the exchange rate commitment on 6 April 2017, the CZK exchange rate strengthened above this limit, which the CNB tried to dampen by buying a huge amount of exchange reserves. Each such koruna will bring a loss to the CNB. Since leaving the exchange rate commitment, the CZK/EUR exchange rate has appreciated by 
more than $9 \%$, except for 2020, where the strong impact of the COVID-19 pandemic can be seen. Investors began to move massively to the markets of safer economies, where the Czech Republic still does not belong, as a result of which the Czech koruna depreciated. As can be seen in Chart 10 above, after the effects of the COVID-19 pandemic disappear and the stabilization of the Czech economy, the CZK exchange rate can be expected to return to prepandemic levels, to around $25 \mathrm{CZK} / \mathrm{EUR}$. Such and greater strengthening of the currency can mean huge losses for the CNB.

The CNB also holds exchange reserves in the form of bonds and shares, making it a participant in the capital market. This can mean some risks for the CNB.

1. The CB does not have sufficient information about the instruments and entities in which it invests on the capital market, as a result of which it does not have a certainty of return.

2. The CB invests through market indices that are cyclical, which may mean some losses in the future.

3. At the time of the need to sell the securities held, there may be insufficient or even no demand in the market, which may lead to high losses.

\section{Chart 11: Selected Items from the CNB's Profit and Loss Statement in CZK Millions}

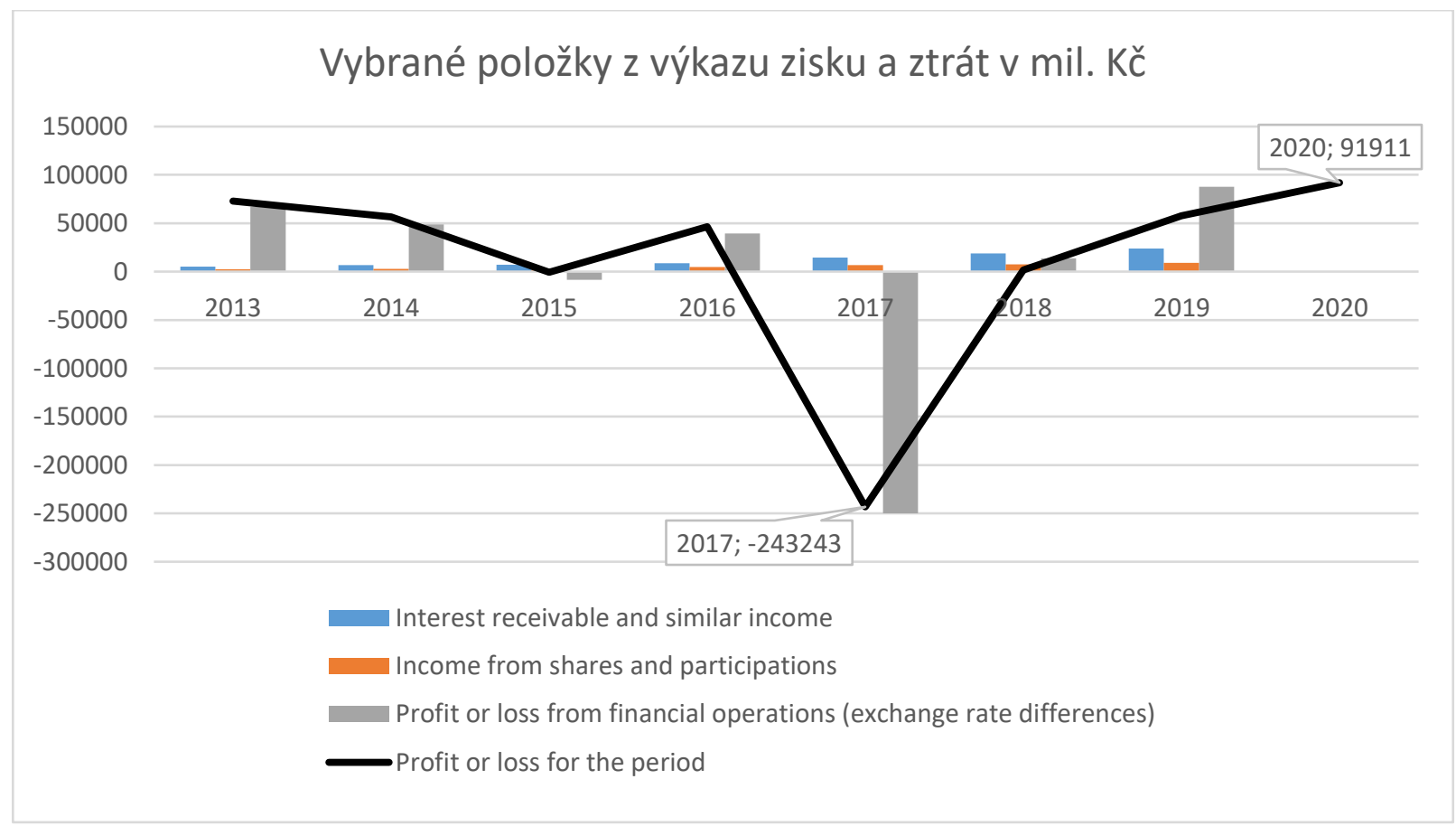

Source: CNB (2013, 2015a, 2017b, 2019b, 2021a). Own processing

The CNB has been challenged in recent years in the ECB's Convergence Reports due to the negative level of equity, which is said to adversely affect the CB's ability to perform its tasks (CNB, 2010). As a result of foreign exchange interventions, the CNB was in cumulative negative values (see Chart 11 above - as of 31 December 2017, the loss for the accounting period was CZK -243,243 million, while share capital and reserves were only CZK 61,726 million) (CNB, 2021a). The CNB currently has a profit of CZK 91,911 million for the accounting period as of 31 December 2020, however, with the Czech koruna strengthening after the effects of the COVID19 pandemic stabilized and subsided; in the event of a changeover to the euro; or tightening of monetary policy, the CNB can be expected to return to negative values.

It should be noted that even though the CNB operates independently of the state and its losses do not have a direct impact on taxpayers, its profits can in rare cases be transferred to the state budget. An example of this is the current emergency in connection with the COVID-19 pandemic and the growing state budget deficit. The CNB recorded a significant gain on the holding of 
exchange reserves due to the weakened koruna during last year, up to around CZK 200 billion. It is important to note that this is only an "accounting profit" caused by the revaluation of the exchange reserves by the weaker koruna. Even though there is a room for the transfer of the remaining "profit" to the state budget, this is only a one-off effect of the weak koruna, which may fade quickly. If the koruna strengthens in the future, the CNB may fall into long-term losses again.

\subsection{The ECB and Purchasing Programs Regarding Real Inflation}

The ECB's balance sheet provides detailed information on how monetary policy instruments are used, ie how the CB conducts monetary policy in both standard and crisis times. At the end of 2020, the balance sheet total reached a historic high of EUR 5.7 trillion (see Chart 12 below).

\section{Chart 12: Development of the ECB's Consolidated Balance Sheet - the Main Items on the Assets Side in Billions of EUR}

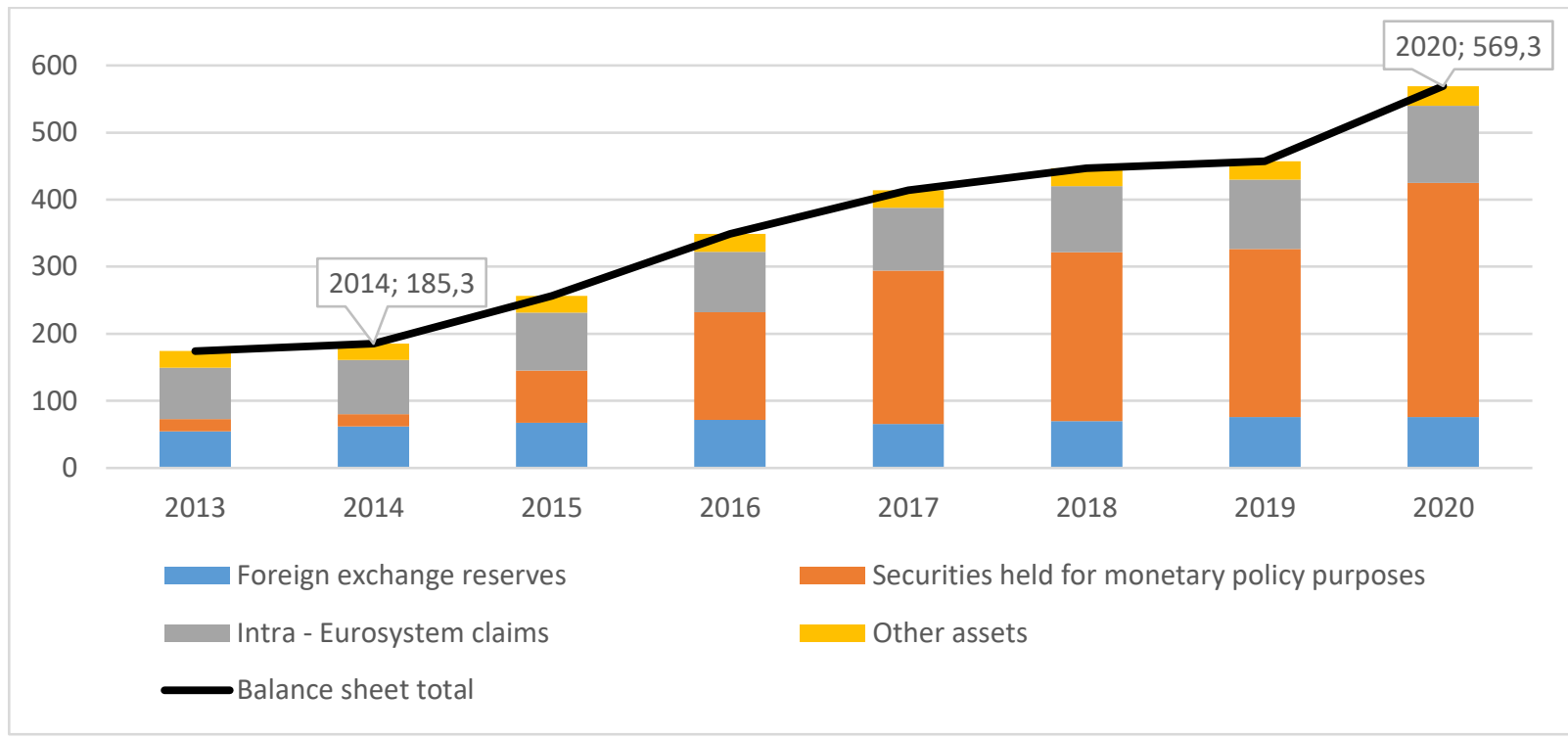

Source: ECB (2017, 2020). Own processing

Since the onset of the global financial crisis in 2007-2008, the ECB has adopted a number of standard and exceptional monetary policy measures that have had a direct impact on the size and composition of the ECB's balance sheet over time (see Charts 12 and 13). Extraordinary measures included secured credit operations for counterparties with an initial maturity of up to four years, as well as purchases of assets issued by private and public entities (under APP) applied since 2015. During the quantitative easing period, the balance sheet total more than tripled.

These purchases led to an increase in "securities held for monetary policy purposes". At the same time, the cash settlement of these purchases led to a corresponding increase in "intraEurosystem liabilities" (see Charts 12 and 13). At the end of 2020, securities held for monetary policy purposes reached $61 \%$ of the ECB's total assets. 
Chart 13: Development of the ECB's Consolidated Balance Sheet - the Main Items on the Liabilities Side in Billions of EUR

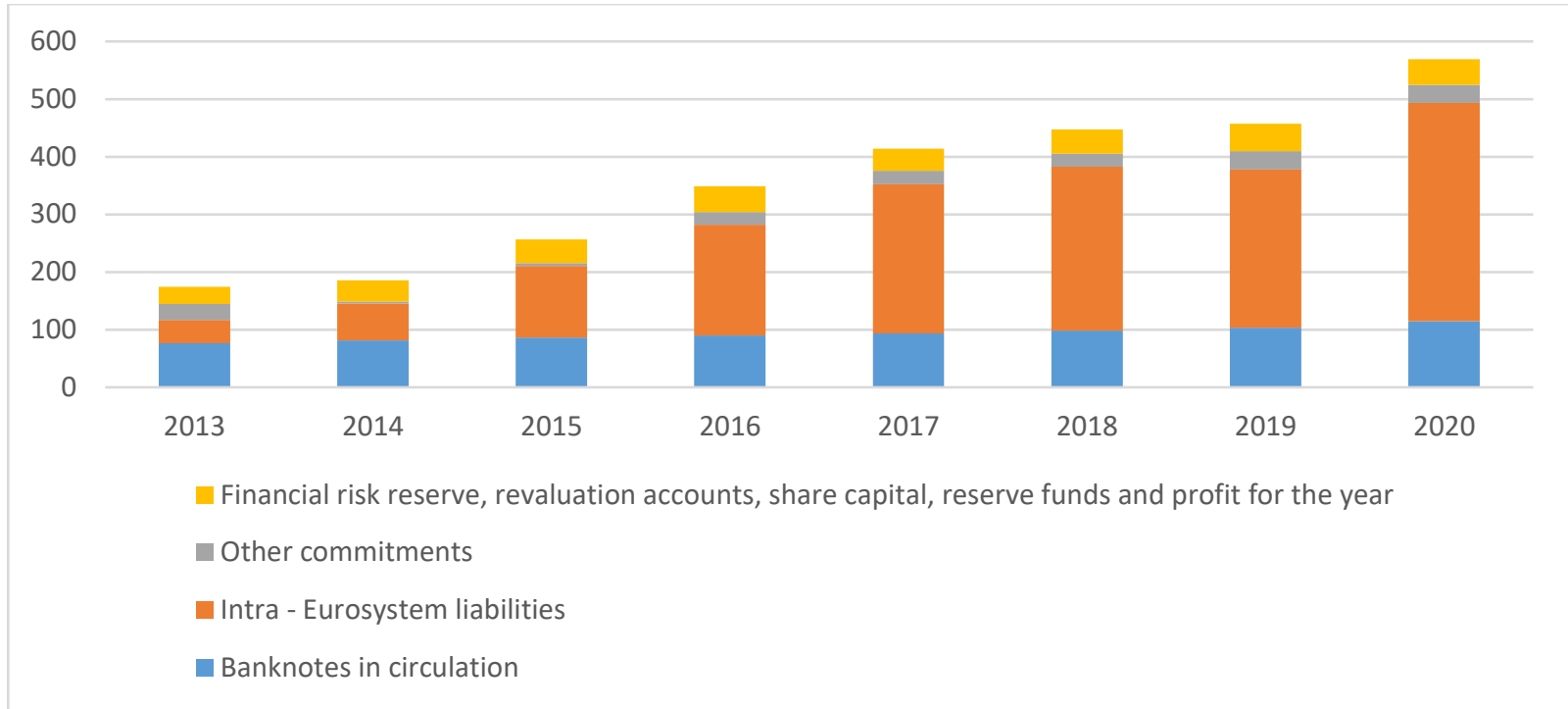

Source: ECB (2017, 2020). Own processing

Chart 14 below shows the composition of the asset purchase in the APP program. ABSPP accounted for $1 \%$ (EUR 29.3 billion), CBPP3 for $9 \%$ (EUR 287.5 billion) and CSPP for $8 \%$ (EUR 250.4 billion) of total assets held at the end of 2020 under APP. The PSPP accounted for a significant part of the APP program, reaching EUR 2.4 trillion at the end of 2020, meaning 81 $\%$ of all assets held under APP (ECB, 2020).

Chart 14: Cumulative Net Purchases of the APP Program in Billions of EUR - According to Individual Programs

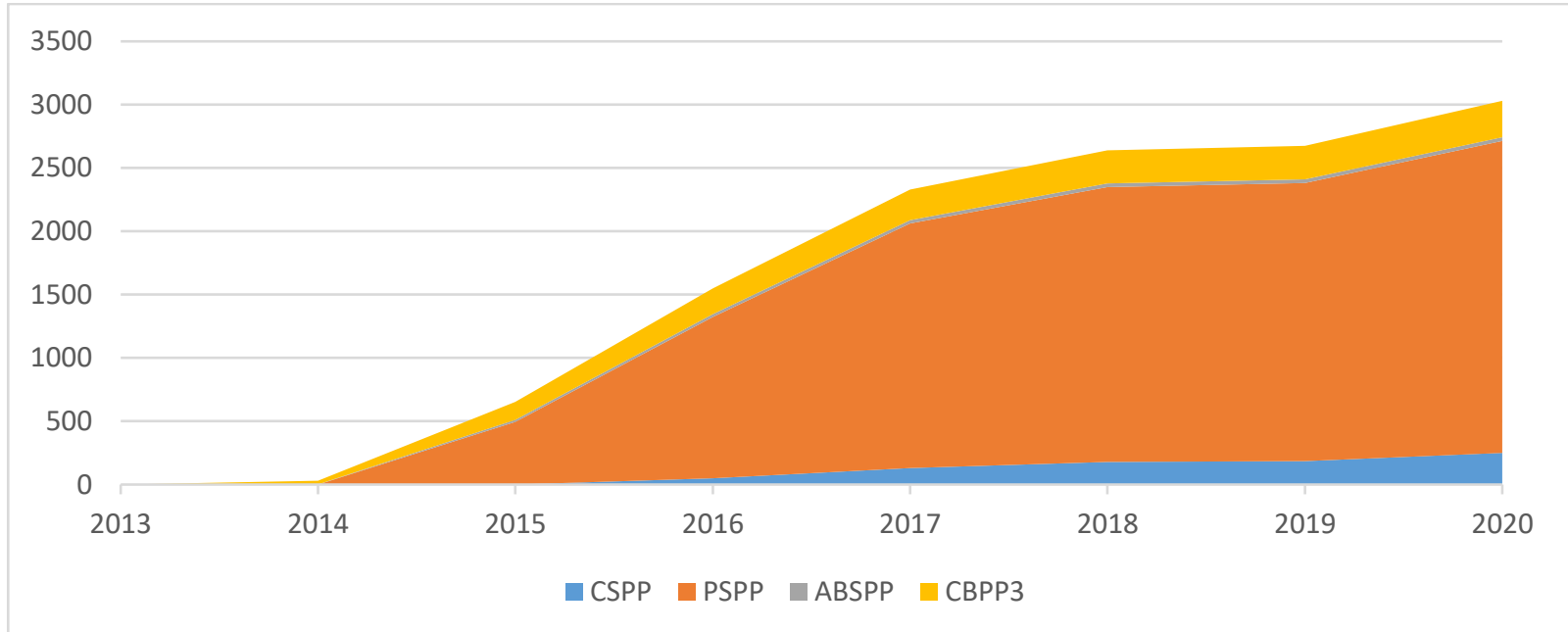

Source: ECB (2021a). Own processing

In 2020, the ECB's total assets increased by a further $24.5 \%$ compared to 2019 , for a total of EUR 112.2 billion. As can be seen in Chart 15 below, this was a $34.5 \%$ increase in terms of holdings of securities held for monetary policy purposes worth EUR 98.6 billion. This increase was mainly due to the APP program and the purchase of securities under the new Emergency Pandemic Asset Purchase Program (PEPP). The Governing Council decided on the PEPP program to address the serious risks to the monetary policy transmission and the outlook of the euro area posed by the covid-19 pandemic. 


\section{Chart 15: Securities Held for Monetary Policy Purposes in Billions of EUR}

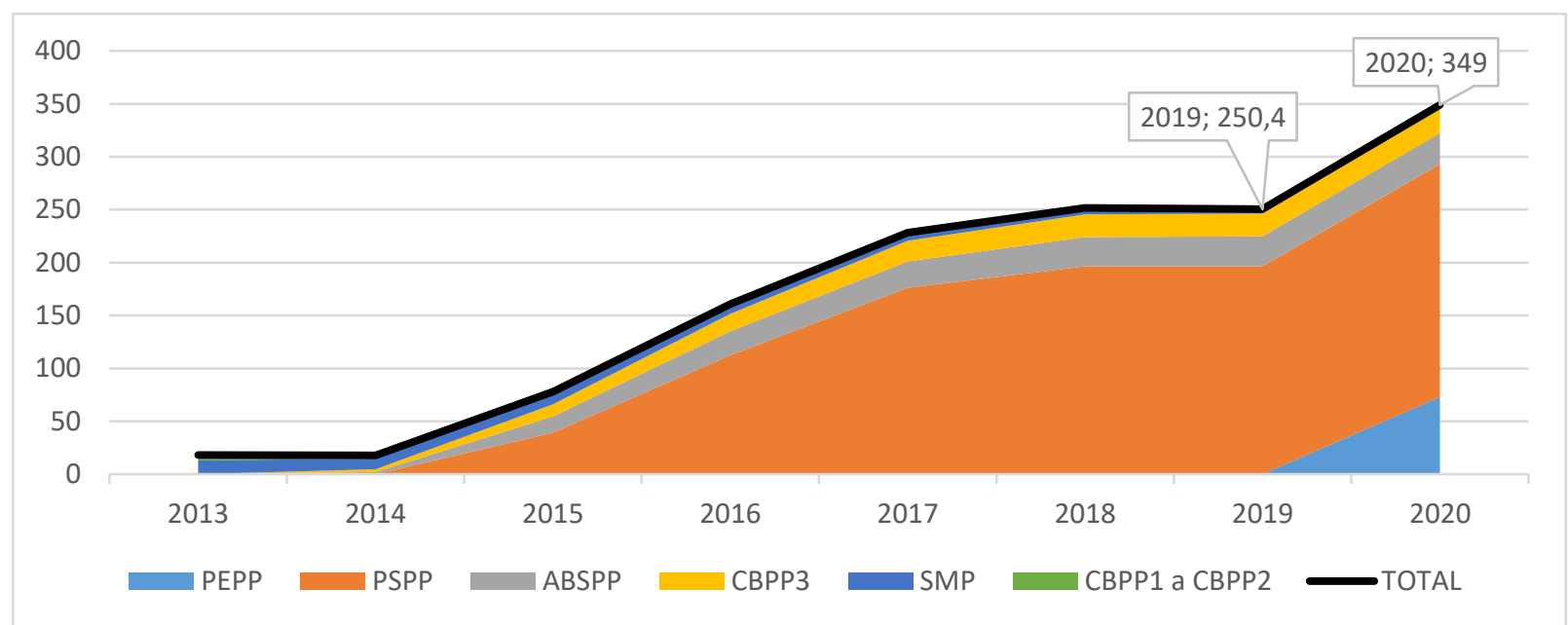

Source: ECB (2017, 2020). Own processing

The ECB expected that its APP program (in particular the purchase of securities under the PSPP) would prevent deflationary pressures affecting the Eurozone economy and persuades economic agents to change their inflation expectations to rising levels. For economic agents to change their inflation expectations, the foundations must be laid in real growth of the inflation rate towards the required value. As can be seen in Chart 16 below, there has been no correlation between the development of the ECB's HICP and purchasing programs in recent years which aimed to bring inflation closer to below 2 pp Although the volume of securities held by the ECB for monetary policy purposes has been growing steadily and significantly in recent years, inflation is not the same.

Chart 16: HICP Developments in the Eurozone Relative to the Volume of Securities Held by the ECB for Monetary Policy Purposes

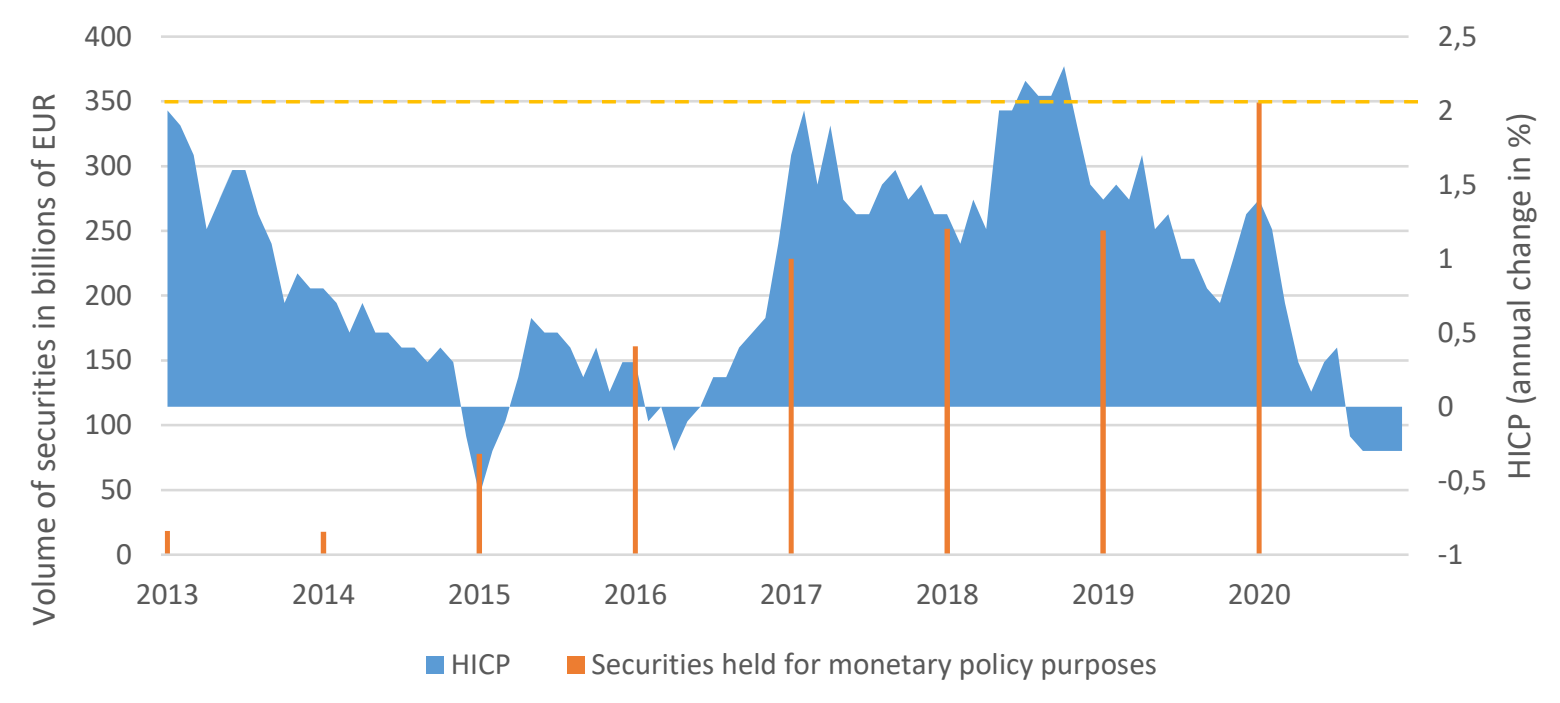

Source: ECB (2017, 2020, 2021c). Own processing

Bloomberg (2020) confirms this statement with a regression analysis, comparing the inflation rate with the ECB's balance sheet. The analysis indicates that there is almost no relationship between the size of the ECB's balance sheet and realized inflation. This conclusion may suggest that the ECB is making large purchases of government and corporate bonds in order to reduce the costs of financing Eurozone government debt by squeezing government bond yields to maturity to a lower level than it would have had without these purchasing programs. Furthermore, the statement of the German Constitutional Court, which for the first time in its 
history opposed the opinion of the European Court of Justice and described the ECB's main policy of quantitative easing (specifically the PSPP program) as theoretically unconstitutional.

Another prerequisite for success of $\mathrm{QE}$ is that commercial banks gradually release liquidity into the economy from their reserves accumulated during purchasing programs of $Q E$ and the inflation rate starts to rise gradually, thus meeting the ECB's primary goal of launching this program.

The problematic aspect here stems from the loss of the control mechanism. The ECB has no control over where commercial banks send money, nor does it have any leverage on the Eurozone member countries. However, in terms of trust, it is important that the countries use their resources to support the economy, so that the ECB has succeeded in achieving its goal improving the transmission of monetary policy and easing financing conditions in the Eurozone.

Nonetheless, the QE program has so far failed to influence the inflation expectations of economic agents. The question is whether the banks released the liquidity received for the sale of securities in sufficient quantities to the economy in the form of loans. However, it is possible that banks continue to hold excess liquidity in their reserve accounts to increase their capital adequacy.

There is a risk that if the banks suddenly released the liquidity held so far into the economy, there would be a possible subsequent effect in the form of hyperinflation. It must be stated that the hyperinflation scenario has not yet been confirmed by the Fed, Bank of England, or Bank of Japan, which have experience with QE.

The reason may be stricter regulation of the financial sector and a general reluctance to provide new loans. Those are perceived as too risky in the current economic conditions of the CBs, which leads to a slowdown in the speed of money circulation in the economy. Nevertheless, hyperinflation can also occur in other ways through QE. Although inflation does not directly affect consumer prices, it can occur in higher asset prices. This can lead to market bubbles in stock, commodity, and land markets.

\section{CBs' Credibility and Fulfilment of Their Key Mandate}

CB's communication with the public plays an important role in the inflation targeting regime. The cornerstone and building block of this communication are documents that are regularly published and contain macroeconomic forecasts and assessments of the past period and economic development. In the case of the CNB, these are the quarterly Inflation Reports; in the case of the ECB, the quarterly Macroeconomic Projections for the Eurozone can be mentioned.

The basic belief of CBs is the confidence of financial markets, credit rating agencies and the public. Only a credible monetary policy can effectively influence inflation expectations, and thus minimize costs in securing its main goal, maintaining the price stability. The purpose of the regular issuance of quarterly Inflation Reports or Macroeconomic Projections is therefore the CB's effort to make their activities transparent, comprehensible, predictable, and consequently credible.

However, CBs also need to fulfil their basic mandate of maintaining financial stability to build and maintain credibility. Here is an interesting look of the authors Claudio Borio and Anna Zabai (2016), who point out that the growing reliance on unconventional politics is not so much a cause as a consequence of deeper error lines. One of these lines is the nature of the recession and the subsequent recovery that brought the debt crisis. Another one is the unbalanced combination of post-crisis policies, which left monetary policy to bear most of the burden, or forces that stubbornly kept inflation low and below the set inflation target and which drastically narrowed the CBs' options. Finally, it is worth mentioning the probably less than fully adequate framework of the current CB monetary policy - a framework focused on short-term inflation control, which is at odds with maintaining financial stability, despite the potential huge macroeconomic costs. 


\subsection{In Terms of Resulting Inflation}

From the point of view of the resulting inflation, it must be stated that despite the use of a wide set of unconventional monetary policy instruments, inflation in Europe was only achieved after many years of efforts. When the crisis recurs, it is doubtful whether the CBs will be able to cope with their monetary and stabilization challenges. An example can be the current covid-19 pandemic, which will leave states with a huge increase in state budget deficits and in times of recession.

\section{Chart 17: Development of HICP of the Czech Republic and the Eurozone in 2007-2019}

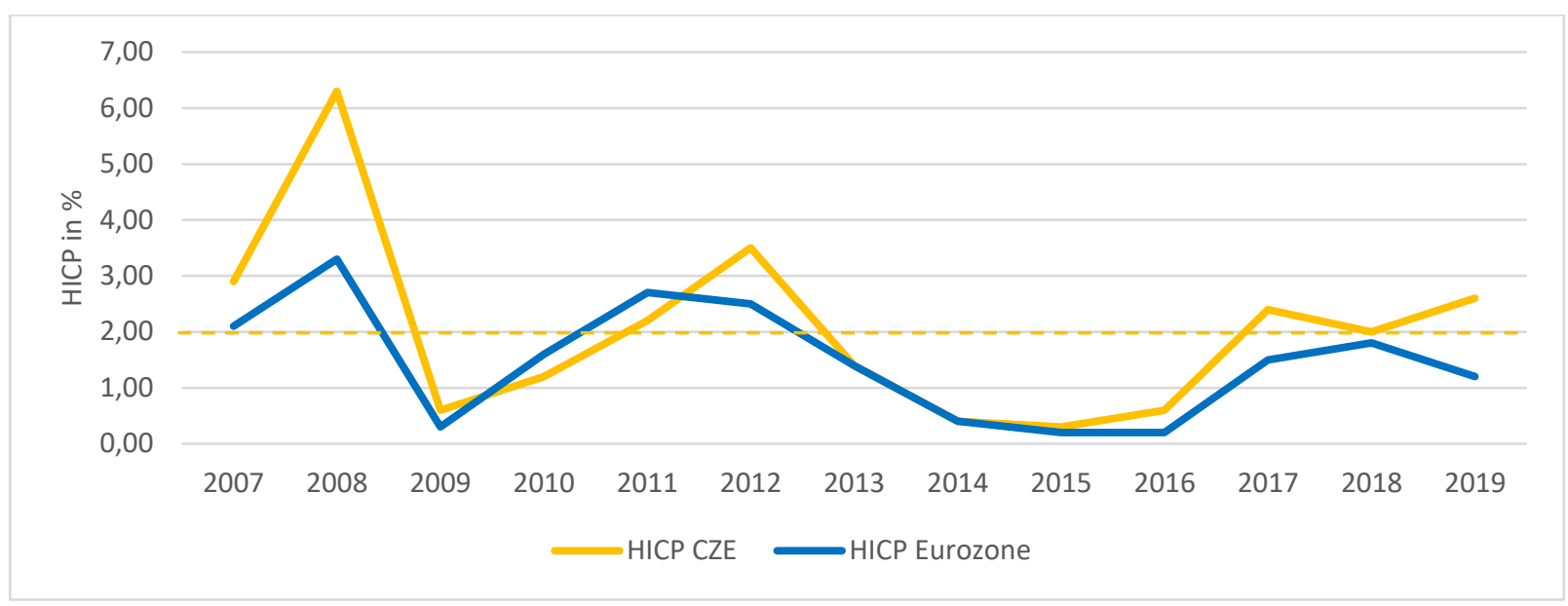

Source: EUROSTAT (2021b). Own processing

When comparing the CNB's and the ECB's approaches to the crisis, the CNB's approach can be described as more appropriate in terms of resulting inflation, as it began to bring inflation closer to the set inflation target a year earlier than in the case of the Eurozone, see Chart 17 above. As a result, it was able to choose to exit unconventional monetary policy earlier than the ECB and return to using standard instruments faster. While the CNB left its exchange rate commitment on 6 April 2017 and increased its main 2W repo rate by a total of 9 times by the beginning of 2020, the ECB's QE continues (reinvestment phase under APP and new purchases under PEPP) and the ECB has still been keeping its main refinancing rate at zero.

Within the evaluation from the point of view of the resulting inflation, it is appropriate to mention the issue of deflation. According to the analysis, it is undoubtedly that the entire Eurozone was facing deflationary pressures. The question remains whether deflation was really a threat. Graph 18 and Table 1 below show the impact of regulated prices on inflation in the Czech Republic and the Eurozone, which significantly pushed down inflation. Regulated prices are both outside the scope of monetary policy and deflation on the supply side. In other words, it was a positive deflation that was not a threat to states, as in the case of demand-side deflation. 
Chart 18: Impact of Regulated Prices on Inflation in the Czech Republic in 2013-20

(in pp)

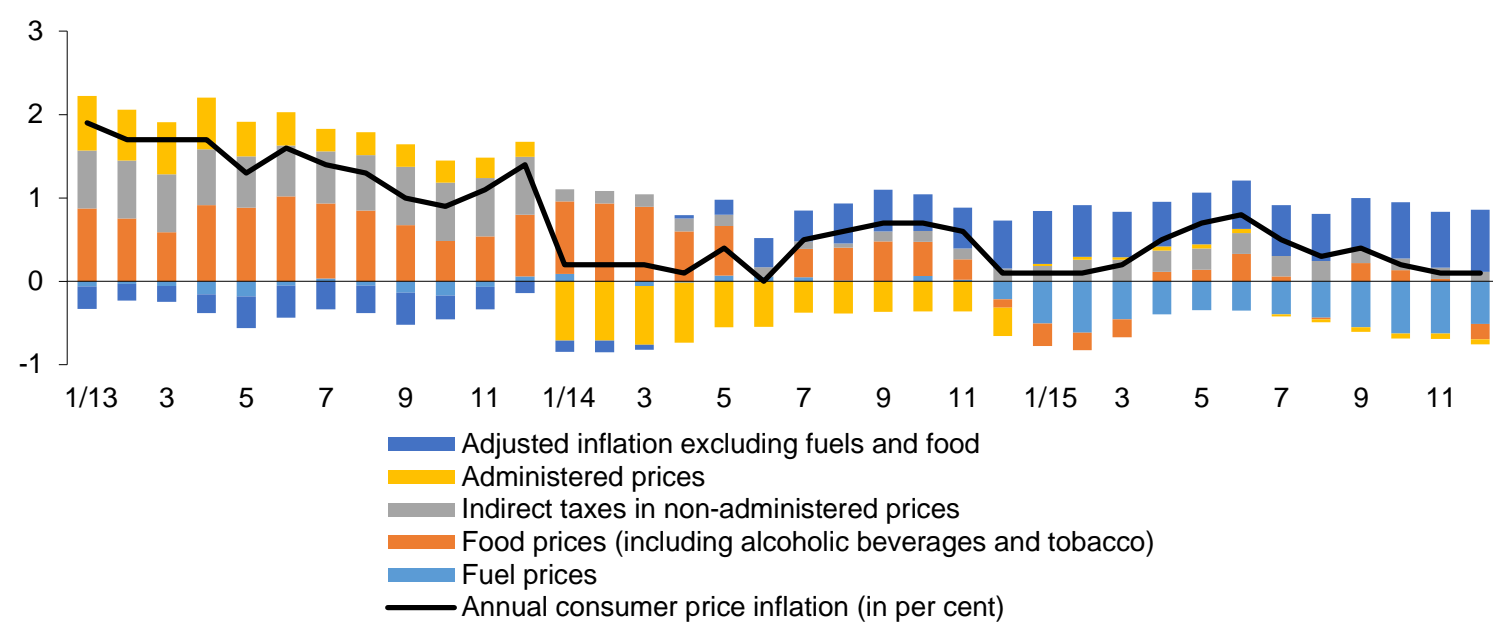

Source: CNB $(2014,2015 b)$. Own processing

In Chart 18 can be observed that in the course of 2014, headline inflation in the Czech Republic pushed the decline in the regulated part of the consumer basket significantly downwards. The most obvious item was telecommunications, which still reflected the introduction of unlimited mobile tariffs in 2013. The impact of energy prices was also evident, the expected reduction in electricity and gas prices were observable there (CZSO, 2017a). It is also worth mentioning the decrease in the health item, which was mainly due to the abolition of the hospital stay fee (CZK 100) (CEVRO, 2014). As Pavel Řežábek, then a member of the CNB's Bank Board, commented, if we look specifically at which prices fell the most, it is electricity and gas with an impact on inflation of $-0.8 \mathrm{pp}$. They are pulling inflation down if it weren't for them, inflation is above one percent and there would be no drama (Zavadilová, 2014). In combination with health and telecommunications, the impact of regulated prices on inflation was indeed significant, as it exceeded $1 \mathrm{pp}$.

The regulated part of the basket is worth mentioning in 2015 as well, as it had a significant effect on headline inflation, especially in the form of the abolition of regulatory fees in healthcare (effective from 1 January 2015). That caused a significant drop in prices in this regulated part of the consumer basket. The unexpected drop in oil prices, which was reflected in the development of producer prices, was also significant (CZSO, 2017a).

\section{Table 1: Impact of Regulated Prices on Inflation in the Eurozone in 2014-2016}

(in pp)

\begin{tabular}{|l|r|r|r|}
\hline \multirow{2}{*}{\begin{tabular}{l} 
Regulated prices \\
\cline { 2 - 3 }
\end{tabular}} & \multicolumn{2}{|c|}{ Contribution to annual inflation } \\
\hline Electricity, gas and other fuels & 2014 & 2015 & 2016 \\
\hline Transport & -0.04 & -0.24 & -0.26 \\
\hline Communication & -0.01 & -0.36 & -0.19 \\
\hline TOTAL & -0.09 & -0.02 & 0 \\
\hline
\end{tabular}

Source: EUROSTAT (2021). Own processing

In addition to the unexpected fall in oil prices (see table 1 above), the fall in prices in the regulated part of the basket (especially on the energy side) was reflected in headline inflation in the Eurozone, especially in 2015-2016. 


\subsection{In Terms of Interest Rates Cuts}

The CNB was one of the first CBs in the world to ease monetary policy in response to the outbreaking crisis. The CNB continued to cut its interest rates as early as August 2008 (see chart 19 below). It continued to decline gradually (possibly stagnation) in 2011, despite slight inflationary pressures.

\section{Chart 19: Development of the ECB's and CNB's main interest rates in 2008-2020}

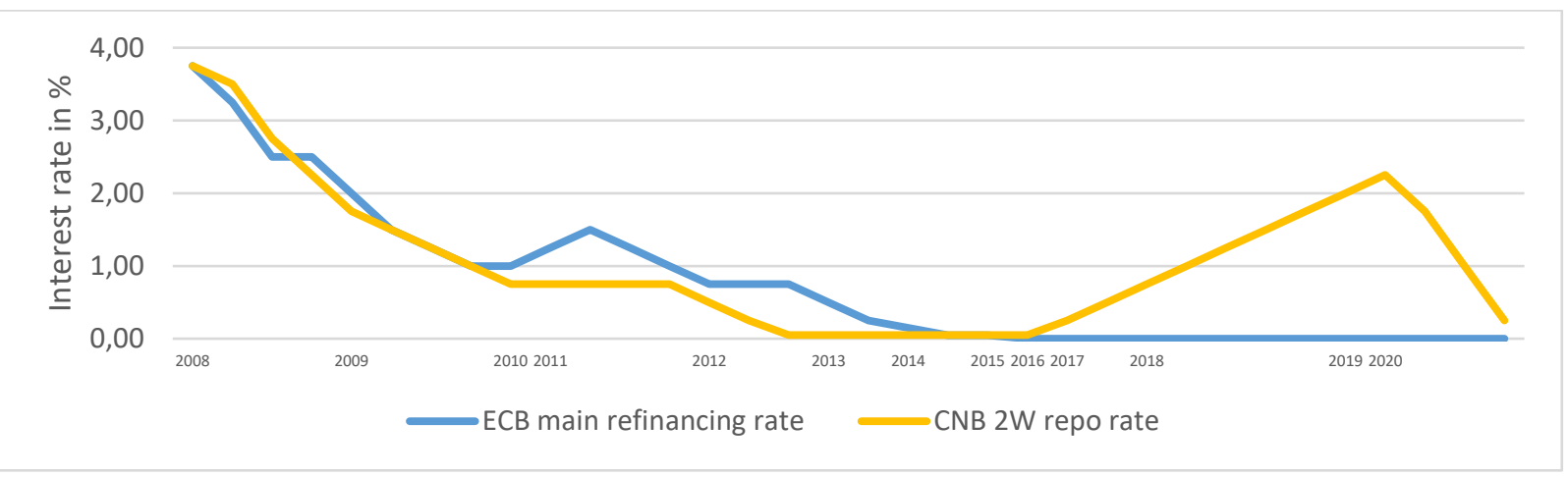

Reference: CNB (2021c), ECB (2021b). Own processing

The ECB also gradually reduced its main refinancing rate from the onset of the crisis. However, the exception in the first half of 2011 can be considered significant, when interest rates rose by $0.5 \mathrm{pp}$. The ECB's decision was based on the economic recovery that prevailed in the euro area at the beginning of the year, as well as on pro-inflationary tendencies. Nevertheless, the CNB's decision to insist on the same interest rates compared to the ECB's move to raise rates may be considered more appropriate over time.

The Governing Council's decision to increase the key ECB interest rates by as much as $0.5 \mathrm{pp}$ in 2011 was only a solution to short-term inflation fluctuations. If we consider the effectiveness of the transmission mechanism in influencing interest rates, we are talking about a period of 12 18 months. The ECB's decision to raise key interest rates in 2011 thus affected the economy in more than a year's lag, when the Eurozone was already under threat of deflation and had to dampen disinflationary pressures.

Lastly, it is worth mentioning the discrepancy between fiscal and monetary policy, which did not only prevail in the Czech Republic, but the impact of further fiscal consolidation efforts on domestic demand was also observed in some countries of the Eurozone (ECB, 2012). Pavel Řežábek, then a member of the CNB's Bank Board, drew attention to the fiscal and monetary policy mismatch and commented on the gradual reduction of the CNB's key interest rates in 2012. Government's measures to consolidate public finances partly negated the Czech National Bank's efforts to ease monetary conditions, when tax growth was holding back domestic demand, which helped to exacerbate the cyclical downturn in the economy (Mlčochová, 2012). A greater interplay between monetary and fiscal policy at first would have been preferable. Nonetheless, that moment, both policies - fiscal and monetary - behaved differently to the economic cycle. It would have been appropriate for fiscal policy to help restore real convergence (Mlčochová 2012). The legitimacy of the reduction of key interest rates to technical zero itself can also be discussed, as a result of which the CNB could not have used its basic tool by which it influenced inflation expectations in the Czech economy anymore. 


\subsection{In Terms of Chosen Unconventional Monetary Policy Instrument}

For a small open economy, such as the Czech Republic, with a shallow secondary capital market, the quantitative easing strategy provided little, if not zero, scope. Therefore, the CNB, unlike other CBs, did not purchase government and private securities during the financial crisis. Instead, an exchange rate commitment was chosen for the Czech economy under the given conditions. From the point of view of easing monetary conditions, the exchange rate commitment can be described as a step in the right direction, as over time inflation has managed to return to the set inflation tolerance band and move closer to the set inflation target. On the other hand, there was a sharp increase in foreign exchange reserves, which could mean huge losses for the CNB in the future caused by the appreciation of the domestic currency against the euro. The Czech Republic's entry into the ERM II system can also be expected in the future, where again the amount of foreign exchange reserves may mean a complication for the CNB in the event of losses caused by the setting of the entry rate by the European Commission and the ECB.

At the same time, it is important to realize that the economy is not built on just one strong measure. The economy is more complex than just relying on one monetary policy decision. It is therefore not surprising that the exchange rate measure was a minority rather than a major success in terms of economic turnover. According to the analysis of the period under review, the trend in GDP has changed since the first quarter of 2013. It can be concluded that economic growth could not be the result of mainly exchange rate interventions, as it began about 2-3 quarters before the exchange rate commitment was introduced. However, the effect of the exchange rate commitment on GDP growth can no longer be ruled out in the course of 2014, but in the course of 2013 verbal interventions, which were evident by the CNB as early as 2012 , would have to suffice to suppress the expected deflationary tendencies. Nonetheless, during 2011-2016, in summary, GDP growth was mainly due to a change in the economic cycle.

The transmission of monetary policy in the exchange rate regime is faster than in the case of interest rates. Therefore, if the use of the exchange rate commitment were as justified as the CNB claimed and subsequently set correctly, the inflation rate should have been at its inflation target by the end of 2014 at the latest, which did not happen. However, the further extension of the exchange rate commitment and the postponement of the exit with regard to future years did not have the same effect on inflation as it would have been with the use of key interest rates.

In the case of the ECB's monetary policy assessment, the main reason why the quantitative easing program did not produce the expected result a poor diagnosis of the Eurozone's problems can be considered. The European problem was thought to be a question of demand and liquidity. As it turned out, it was caused by an excess. The ECB has come under enormous pressure from banks and governments to implement a program like quantitative easing in the US. However, if we look a few years back, the euro area has been under a chain of government stimulus since 2009 and that the Eurozone's problem cannot be seen in liquidity as in its interventionist economic approach.

The functioning of banks and the ways in which they are financed are crucial for the Eurosystem. For this reason, in order to reduce the financing costs of the real sector, it is necessary to help reduce the financing costs of banks, especially their medium-term resources. Therefore, the purchase of covered bonds with low risk and a strong link to long-term bank financing was chosen for longer maturities. Nevertheless, as Weidmann (2018, p.2) commented "today, ten years after the financial crisis escalated, policy rates are still at historic lows. The Eurosystem has accumulated a huge portfolio of securities of various kinds, and refinancing operations offered to banks have remained more than generous. As a result, excess liquidity stands at a level nine times higher than after the Lehman collapse, and monetary policy is roughly as expansionary as it was when the crisis was raging. Put differently, the remaining policy space is rather limited." 


\section{Loss of CBs' Credibility}

Unconventional instruments initially took the form of providing liquidity to frozen markets in several countries. The supply of liquidity solved the liquidity problems of the interbank market, which operates without collateral, and which froze at the beginning of the financial crisis. However, the supply of liquidity does not automatically mean a loosening of monetary policy.

Given developments in recent years, the use of unconventional monetary policy instruments, such as quantitative easing or foreign exchange interventions, may seem increasingly common practice for the CBs. As supporting evidence can be considered the study by Claudio Borio and Anna Zabai (2016), who point out that these so-called unconventional monetary policy instruments, which were adopted with the advent of the debt crisis (2012-2015), have become commonly used instruments over the last few years.

This study also highlights the combination of unconventional monetary policy and declining yields. The ratio between revenues and costs changes over time to the benefit of costs. Not to mention the problems associated with exiting these policies. The authors point out that although the benefits may seem sufficient in the short term, in the longer term, more damage may prevail. As part of the use of these tools, CBs are also reducing their room for maneuver and, as a result, their ability to cope with the ensuing recession, which is inevitable over time. The overall pressure to use more and more experimental measures, unpredictable at best and dangerous at worst, may become too strong at some point. As a result, the credibility and legitimacy of the CBs may be called into question (Borio, Zabai, 2016).

\subsection{Monetization of Government Debt and Interpretation of the Treaties by the ECB}

The ECB's idea was similar to the Fed's idea of buying financial assets, including the sovereign debt of euro area member countries, as well as assets from agencies and institutions. Due to the institutional set-up of the euro area, the ban on monetary financing in the EU and restrictions on its circumvention, buying government bonds, for example through quantitative easing, is not as straightforward as in the US or the UK. The ECB is prohibited from financing states directly (see Article 123 on the functioning of the European Union) (Parlament ČR, 2008). Therefore, the ECB may be referred to when using legal loopholes. One such program is the SMP (or OMT) program, where the ECB has been accused of circumventing the treaties.

Critics of bond purchases are of the opinion that the purpose of this provision is to prevent the financing of governments' debts through the purchase of their bonds not only on the primary market but also on the secondary market. Their first argument refers to the wording of Council Regulation EC 3603/93, which clarifies the definition for the application of the above prohibition and states, inter alia, that member states must take appropriate measures to ensure that the prohibitions laid down in Article 104 of the Treaty (currently Article 123 SFEU) have been effectively and fully respected; that, in particular, secondary market repurchases may not be used to circumvent the purpose of this Article. ${ }^{5}$ Another type of loan means "any financing of the public sector's liabilities to third parties" or "any operation with the public sector which gives rise or may give rise to a claim on it. ${ }^{6}$ However, at its meeting on 11 January 2017, the ECB stated that the securities purchase program fully complies with the Eurosystem CB's obligations under the Treaties, including the prohibition of monetary financing, and thus does not undermine the Eurosystem in accordance with the open market economy (The Governing Council of the ECB, 2017).

Over time, it can be speculated that the purpose of the ECB's purchasing programs (within the APP) was not in fact to intensify monetary policy expansion and inflation, but to keep alive the governments of peripheral euro area countries threatened by drying demand for their bonds, and European banks facing major losses on the bonds they hold.

\footnotetext{
${ }^{5}$ Recital 7 of Council Regulation (EC) No 3603/93 of 13 December 1993 specifying definitions for the application of the prohibitions referred to in Articles 104 and 104b of the Treaty. Official Journal L332 / 1, 31.12.1993.

${ }^{6}$ Art. 204 of Council Regulation (EC) No 3603/93 of 13 December 1993 specifying definitions for the application of the prohibitions referred to in Articles 104 and 104b of the Treaty. Official Journal L332 / 1, 31.12.1993.
} 
Other than the purely monetary-political motivation can be read from the fact that purchases were sterilized until June 2014. In other words, the money newly created through the purchase did not have an impact on the real economy. In the case of the ECB, the tendency to talk about QE only since 2015 is therefore because this was the first purchasing program that the ECB really started to implement mainly to avoid the threat of deflation (increase inflation).

\subsection{Amendment to the CB's Act and Greater Power for the CB}

On 8 April 2020, the Chamber of Deputies of the Parliament of the Czech Republic approved the so-called "small" Amendment to the CNB Act, which is based in part on the original Amendment to the CNB Act, which the CNB has been seeking to approve since 2016. This amendment addresses 2 important areas:

- the legal authority to set limits on mortgage loan indicators,

- the CNB's open market business.

The draft Amendment to the CNB Act was largely triggered by the CNB's policy. To meet the $2 \%$ inflation target it adopted a less standard exchange rate commitment regime at almost zero rates, which aroused great interest in "low-rate" mortgages. As a result, a possible real estate bubble has formed on the Czech market, which the CNB currently wants to dampen by regulation, which is already a non-market instrument. In essence, this means that the CNB does not have confidence in the management of individual financial institutions. As a result, the adoption of such an amendment may mean the exclusion of part of the population from the possibility of purchasing reasonable housing.

This "small" Amendment was discussed by the Chamber of Deputies in a state of legislative emergency as one of the important measures to combat the effects of the COVID-19. In connection with pandemic the Amendment was extended to the area of CNB's financial market trading without restrictions on possible instruments, maturity and counterparty (CNB, 2020c). According to the Ministry of Finance, the Amendment to the CNB Act will enable better coordination of monetary and fiscal policy (Vláda ČR, 2020).

Thanks to the Amendment, the CNB can trade in securities with a maturity of more than 1 year, as well as with more entities, such as insurance companies, pension companies and other investors who are ordinary holders of government bonds. In other words, the CNB will be allowed to indirectly monetize the state debt.

Contrary to the original draft of the Amendment, the deputies approved the expansion of the CNB's trading instruments and counterparties only until the end of 2021 (CNB, 2020c). The fact, that the Ministry of Finance will most likely try to cover the state budget deficit from the previous and current year by issuing bonds, is probable. As a result of the pandemic, the state is in a situation where it will have to borrow significantly more than in previous years, at a time when there is great uncertainty in world markets. According to ING economist Jakub Seidler, for the state not to get into a situation where the market is not interested in its bonds, or to avoid having to borrow at very high interest rates, the CNB will be able to send a signal that it is interested in these bonds. It will help the state to borrow on the market on more favourable terms (ČTK, 2020). However, this would mean that a huge amount of money would be released into the economy, which could distort the financial markets with assets and the position of ordinary investors.

\section{Conclusion}

The effects and consequences of unconventional monetary policy are the subject and main focus of analyses around the world, yet the results are not convincing. Many economies and national currencies have reacted differently to unconventional monetary policy methods, and for the final consequences we will have to wait. However, it is already certain that in most countries, where unconventional monetary policy instruments played a role, there was no rise in inflation, in some cases rather deflation in terms of transmission. A huge amount of money has been released into the world economy by several nations. Currently, it can be argued that advanced 
economies have recovered from the slump, but the newly generated money has travelled across borders and created a transnational economic bubble in developing economies. The question therefore remains whether, and when these bubbles will burst and how the monetary authorities will react.

In assessing the use of unconventional monetary policy instruments, the income-to-cost ratio changes over time to benefit costs. Not to mention the problems associated with exiting this policy. Thus, although the benefits may be felt in the short term, negatives may prevail in the longer term.

The overall pressure to use more and more experimental measures, unpredictable at best and dangerous at worst, may become too strong at some point. CBs approaches negated the procyclical effect of fiscal policy using unconventional instruments. This "experiment" can be very dangerous for CBs, because they failed to meet their goals within a predetermined time horizon. In case of repetition, their credibility may be called into question.

The reliance on unconventional policies in recent years is not so much a cause as a consequence of deeper error lines. The nature of the recession and the subsequent recovery brought about by the financial crisis can be considered one such line. It is also possible to mention the unbalanced combination of post-crisis policies which left monetary policy to bear most of the burden, or forces that stubbornly kept inflation low and below the set inflation target - forces that drastically narrowed the CBs' options. An example is the consolidation of public finances, and thus the non-cooperation of fiscal and monetary policy; or the threat of deflation, which ultimately had a positive effect on the supply side.

In an effort to meet the inflation target, monetary policy authorities reached technical zero interest rates and began using unconventional instruments. If this situation is long-term, there is a risk that the CBs will come into conflict with other tasks, in particular maintaining financial stability. The result observed in recent years are bubbles in the stock or bond market (Klieber, 2021), commodities market (as documented by Čermáková, 2021) or the real estate market (as documented by Hromada, 2021), or wage pressures across industries as demonstrated by the study of Kadeřábková (2020).

The recent financial crisis has shown that zero interest rates and liquidity traps are not just academic concepts and that unconventional monetary policy instruments, such as quantitative easing in the case of the ECB and exchange rate commitment in the case of the CNB, can now be included in CBs' instruments.

In an effort to answer which CB's approach was a more appropriate alternative in the crisis and post-crisis period, a comparison of approaches to the crisis was made from three perspectives, namely the resulting inflation rate, the rate of interest rate cuts and the choice of an unconventional monetary policy instrument.

In terms of the resulting inflation, it must be stated that inflation target in Europe was only achieved after many years of efforts, despite the use of a wide set of unconventional monetary policy instruments. However, the unconventional instruments are not adapted to long-term use in terms of transmission time. During the next crisis, doubts may arise about the CBs' competencies and their ability to cope with their monetary and stabilization goals. When comparing the CNB's and the ECB's approach, the CNB's approach can be described at first sight as more appropriate in terms of resulting inflation. It began to bring inflation closer to the set inflation target a year earlier than in the case of the Eurozone. This development can be considered as a consequence of the chosen interest rate cuts and the choice of more suitable unconventional instrument. As a result, the CNB was able to choose to exit unconventional monetary policy earlier than the ECB and return to using standard instruments, such as influencing inflation expectations with key interest rates.

Within the evaluation in terms of the resulting inflation, it is appropriate to mention the issue of deflation. Based on analysis, it is undoubted that the entire Eurozone was facing deflationary pressures. However, as time turned out, deflation was a real threat in neither the Czech Republic nor the Eurozone. The significant impact was the fall in regulated prices and oil prices, 
which significantly pushed down inflation. However, regulated prices are outside the scope of monetary policy and deflation was on the supply side. In other words, it was a positive deflation, which was not a threat to states, as in the case of demand-side deflation. Nevertheless, deflation was one of the main arguments of both CBs in the case of monetary policy decisions.

In terms of the interest rate cuts, the CNB was one of the first CBs in the world that started easing monetary policy in response to the outbreaking crisis by gradually lowering interest rates to technical zero. Unlike the ECB, it maintained a "cool head" in 2011, when pro-inflationary pressures threatened and did not raise interest rates. The ECB's decision to raise key interest rates in 2011 thus affected the economy in more than a year's lag, when the Eurozone was already under threat of deflation and had to dampen disinflationary pressures. Thanks to this decision, the CNB was able to curb disinflationary pressures more effectively in the coming years than the ECB.

Nevertheless, it is necessary to draw attention to the inconsistency of fiscal and monetary policy that prevailed across the Czech Republic and the Eurozone. It made monetary policy less effective and standard monetary policy instruments exhausted more quickly, making it impossible to influence inflation so effectively in the coming years. In connection with the interest rates cuts of both banks, it is thus debatable whether the reduction to zero was the right decision. The measures taken at the time to consolidate public finances partly negated the CBs' efforts to ease monetary conditions, as tax growth hampered aggregate demand. That helped deepen the cyclical downturn in the economy.

In terms of the chosen unconventional monetary policy instrument, it can be assessed that the CNB better defined its starting position and selected the instrument regarding its size, openness and liquidity. After the "exhaustion" of the key monetary instrument, such as interest rates without dispute, the CNB chose, under the given conditions, to use the exchange rate commitment, a more effective unconventional instrument for it. However, in the case of the ECB's assessment, one can speak of failure in terms of chosen unconventional instrument, which is primarily based on a misdiagnosis of the Eurozone problems. The European problem was not a question of demand and liquidity. As it turned out, it was in fact caused by a surplus, as the euro area has been under a continuous chain of government stimulus since 2009.

In terms of easing monetary conditions, the CNB's exchange rate commitment compared to the ECB's step can be described as a step in the right direction. The inflation has returned over time to the set inflation tolerance band and approached the set inflation target. On the other hand, there was a sharp increase in foreign exchange reserves, which may, according to developments in the pre-pandemic period, mean huge losses for the CNB in the future caused by the appreciation of the domestic currency against the euro. The Czech Republic's entry into the ERM II system can also be expected in the future, when the amount of foreign exchange reserves also may mean a complication for the CNB in the event of losses caused by the setting of the entry rate by the European Commission and the ECB.

Nonetheless, the Czech economy is not built on just one strong measure. Based on analysis of the period under review, the trend in GDP has already changed since the first quarter of 2013. It can be concluded that economic growth could not be the result of mainly exchange rate interventions, as it had begun about 2-3 quarters before the exchange rate commitment was introduced. The effect of the exchange rate commitment on GDP growth can no longer be ruled out in the course of 2014. However, in the course of 2013 verbal interventions, which were evident as early as 2012, would have to suffice to suppress the expected deflationary tendencies. In summary, regarding the development in 2011-2016, GDP growth was mainly due to a change in the economic cycle.

Lastly, the transmission of monetary policy in the exchange rate regime is faster than in the case of interest rates. Therefore, if the use of the exchange rate commitment were as justified as the CNB claimed and subsequently set correctly, the inflation rate should have been at its inflation target by the end of 2014 at the latest, which did not happen. 
Finally, it is appropriate to point out the moral hazard, market failure, in which both CBs play a role. In the case of the ECB, the theory of moral hazard gets into practice by the confirmation that there is almost no relationship between the realized inflation rate and the size of the ECB's balance sheet. This conclusion may suggest that the ECB is making large purchases of government and corporate bonds to reduce the cost of financing euro area government debt by squeezing government bond yields to maturity to a lower level than it would have been without these purchasing programs. Other than the purely monetary-political motivation can be read from the fact that purchases were sterilized until June 2014. In other words, the money newly created through the purchase did not have an impact on the real economy. The tendency to talk about QE only since 2015 is therefore due to the first purchasing program that the ECB really started to implement, mainly in an effort to avoid the threat of deflation (increase inflation).

Another piece of evidence is the statement of the German Constitutional Court, which for the first time in its history opposed the opinion of the European Court of Justice and described the ECB's main policy of quantitative easing (specifically the PSPP program) as theoretically unconstitutional.

One thing is certain, thanks to the rise in the use of unconventional monetary policy instruments, huge amounts of money have been emitted, currently finding global investment opportunities, increasing the risk of bubbles. In the case of the Czech Republic, thanks to the exchange rate commitment regime at almost zero rates, there was a great deal of interest in mortgages at "low rates". Already at the time of the exit from the exchange rate commitment, a warning about a possible real estate bubble appeared. Here it is possible to see a moral hazard on the part of the CNB. It has been working hard to enforce the Amendment to the CNB's Act since 2016, approved since 2020, which would give it the legal power to set limits on mortgage loan indicators.

Anyhow, moral hazard on the part of the CNB can also be seen in the extension of the Amendment to the CNB's Act to the area of the CNB's free market transactions without restrictions in terms of possible instruments, their maturity, and counterparties. Thanks to the Amendment, it can trade in securities with a maturity of more than 1 year, as well as with more entities, such as insurance companies, pension companies and other investors who are ordinary holders of government bonds. In other words, the CNB will be allowed to indirectly monetize the national debt.

In conclusion, the credibility and independence of the CBs will play a key role in the coming years. It is already seen a similarity in the approach to monetary policy of both CBs, in the case of moral hazard applied in practice, only from a different point of view. The moral hazard theory is applied on the ECB's side by interpretation of existing regulations and 1993 Council arrangements. In the case of the CNB it is a legislative view in approving statutory amendments that give it greater power and a possibility to regulate the market environment. Nevertheless, if the CNB proceeds with the indirect monetization of the state debt, as allowed by the current Amendment to the CNB's Act, it will start the so-called quantitative easing in the Czech Republic.

\section{Acknowledgements}

This research was founded by grant number IP 500040.

\section{References}

\section{Law regulation}

Council Regulation 3603/93 of 13 December 1993 specifying definitions for the application of the prohibitions referred to in Articles 104 and 104b of the Treaty. Official Journal L 332/1, 31 December 1993. 


\section{Online references}

BLOOMBERG, 2020. Kvantitativní uvolňování ECB zatím nemá na inflaci statisticky prokazatelný vliv [online]. CONSEQ, Michal Stupavský. [Accessed: 8. 3. 2021]. Available at: https://www.conseq.cz/about-company/news/kvantitativni-uvolnovani-ecb-zatim-nema-na-inflaci

BORIO, Claudio, ZABAI, Anna, 2016. Unconventional monetary policies: a re-appraisal [online]. BIS Working Papers, No. 570, p. 43. [Accessed: 30. 7. 2019]. Available at: https://www.bis.org/publ/work570.pdf

CEVRO, 2014. Poplatky ve zdravotnictví [online]. Čtrnáctideník. [Accessed 12.12.2017]. Available at: http://www.cevro.cz/web files/soubory/ctrnacni-deniky/2014/14denik 06 2014.pdf

CNB, 2010. ČNB nesouhlasí s Konvergenční zprávou ECB [online]. [Accessed 16.9.2017]. Available at: https://www.cnb.cz/cs/verejnost/pro media/tiskove zpravy cnb/2010/20100512 conve rgence.html

CNB, 2020a. ČNB zásoby zlata nenavýší [online]. [Accessed 8. 3. 2021]. Available at: https://www.cnb.cz/cs/verejnost/servis-pro-media/autorske-clanky-rozhovory-s-predstavitelicnb/CNB-zasoby-zlata-nenavysi

CNB, 2021a. Dekádní bilance [online]. [Accessed 8. 3. 2021]. Available at: https://www.cnb.cz/analytics/saw.dll?Dashboard

CNB, 2021b. Devizové rezervy - časová řada [online]. [Accessed 8. 3. 2021]. Available at: https://www.cnb.cz/cs/statistika/platebni bilance stat/devizove rezervy/drs rada.htm

CNB, 2017. Investiční pozice a zadluženost České republiky vůči zahraničí [online]. [Accessed 12.8.2017]. Available

at: https://www.cnb.cz/cs/statistika/platebni bilance stat/investicni pozice/ip komentar.html

CNB, 2020b. Investiční pozice - komentáŕ k 30. 9. 2020 [online]. [Accessed 8. 3. 2021]. Available at: https://www.cnb.cz/cs/statistika/platebni bilance stat/investicni pozice/investicni-pozicekomentar/

CNB, 2020c. Komentář ke schválení novely zákona o ČNB Sněmovnou [online]. [Accessed 8. 3. 2021]. Available at: https://www.cnb.cz/cs/cnb-news/aktuality/Komentar-ke-schvaleni-novely-zakona-oCNB-Snemovnou/

CNB, 2019a. Kurzový vývoj a zlatá měna [online]. [Accessed 2. 8. 2019]. Available at: https://www.historie.cnb.cz/cs/menova politika/prurezova temata menova politika/3 kurzovy v yvoj a zlata mena.html

CNB, 2021c. Měnověpolitické nástroje [online]. [Accessed 8. 3. 2021]. Available at: https://www.cnb.cz/cs/menova-politika/mp-nastroje/

CNB, 2009. Monitoring centrálních bank - červen 2009 [online]. [Accessed 28. 9. 2019]. Available at: https://www.cnb.cz/export/sites/cnb/cs/menovapolitika/.galleries/monitoring centralnich bank/0902 mcb.pdf

CNB, 2013. Účetní závěrka a zpráva auditora k 31. 12. 2013 [online]. [Accessed 8. 3. 2021]. Available at:

https://www.cnb.cz/export/sites/cnb/cs/o cnb/.galleries/hospodareni/download/ruz 2013 cz.pdf

CNB, 2015a. Účetní závěrka a zpráva auditora k 31. 12. 2015 [online]. [Accessed 8. 3. 2021]. Available at: https://www.cnb.cz/export/sites/cnb/cs/o cnb/.galleries/hospodareni/download/ruz 2015 cz.pdf

CNB, 2017. Účetní závěrka a zpráva auditora k 31. 12. 2017 [online]. [Accessed 8. 3. 2021]. Available at:

https://www.cnb.cz/export/sites/cnb/cs/o cnb/.galleries/hospodareni/download/ruz 2017 cz.pdf

CNB, 2019b. Účetní závěrka a zpráva auditora k 31. 12. 2019 [online]. [Accessed 8. 3. 2021]. Available at:

https://www.cnb.cz/export/sites/cnb/cs/o cnb/.galleries/hospodareni/download/ruz 2019 cz.pdf 
CNB, 2021d. Vybrané devizové kurzy [online]. [Accessed 8. 3. 2021]. Available at: https://www.cnb.cz/cs/financni-trhy/devizovy-trh/kurzy-devizoveho-trhu/kurzy-devizovehotrhu/vybrane form.html

CNB, 2014. Zpráva o inflaci 4. čtvrtletí 2014 [online]. [Accessed 9. 3. 2021]. Available at: https://www.cnb.cz/cs/menova-politika/zpravy-o-inflaci/Zprava-o-inflaci-IV-2014/

CNB, 2015b. Zpráva o inflaci 4. čtvrtletí 2015 [online]. [Accessed 9. 3. 2021]. Available at: https://www.cnb.cz/cs/menova-politika/zpravy-o-inflaci/Zprava-o-inflaci-IV-2015

CZSO, 2021a. HDP, národní účty [online]. [Accessed 8. 3. 2021]. Available at: https://www.czso.cz/csu/czso/hdp narodni ucty

CZSO, 2021b. Hlavní makroekonomické ukazatele [online]. [Accessed 9. 3. 2021]. Available at: https://www.czso.cz/csu/czso/hmu cr

CZSO, 2017a. Index spotřebitelských cen podle klasifikace COICOP - míra inflace [online]. [Accessed 24.11.2017]. Available at: https://vdb.czso.cz/vdbvo2/faces/cs/index.jsf?page=vystupobjekt\&pvo $=$ CEN08C1\&z=T\&f=TABULKA\&skupld $=1773 \& k a t a l o g=31779 \& p v o=C E N 08 C 1$

CZSO, 2021c. Zahraniční obchod - časové rady řady [online]. [Accessed 8. 3. 2021]. Available at: https://www.czso.cz/csu/czso/vzonu cr

CZSO, 2017b. Zahraniční obchod se zbožím - národní pojetí - časové řady [online]. [Accessed 12.8.2017]. Available at: https://www.czso.cz/csu/czso/vzonu cr

ČTK, 2020. Seidler: Vláda chystá prostor pro české kvantitativní uvolňování, rozšiřuje možnosti ČNB [online]. E15. [Accessed 8. 3. 2021]. Available at: https://www.e15.cz/domaci/vlada-chysta-prostorpro-ceske-kvantitativni-uvolnovani-rozsiruje-moznosti-cnb-1367984

Čermáková K, Filho EAH. Effects of Expansionary Monetary Policy on Agricultural Commodities Market. Sustainability. 2021; 13(16):9317. https://doi.org/10.3390/su13169317

ECB, 2021a. Asset purchase programmes [online]. [Accessed 9. 3. 2021]. Available at: https://www.ecb.europa.eu/mopo/implement/app/html/index.en.html

ECB, 2021b. Key ECB interest rates [online]. [Accessed 8. 3. 2021]. Available at: https://www.ecb.europa.eu/stats/policy and exchange rates/key ecb interest rates/html/index. en.html

ECB, 2012. Makroekonomické projekce 2012 [online]. [Accessed 9. 3. 2021]. Available at: https://www.ecb.europa.eu/pub/pdf/other/eurosystemstaffprojections201212cs.pdf

ECB, 2017. Roční účetní závěrka 2017 [online]. [Accessed 9. 3. 2021]. Available at: https://www.ecb.europa.eu/pub/pdf/annrep/ecb.annualaccounts2017.cs.pdf

ECB, 2020. Roční účetní závěrka 2020 [online]. [Accessed 9. 3. 2021]. Available at: https://www.ecb.europa.eu/pub/annual/annualaccounts/html/ecb.annualaccounts2020 0508aea2f9.cs.html\#toc14

ECB, 2021c. Statistical data warehouse [online]. [Accessed 9. 3. 2021]. Available at: https://sdw.ecb.europa.eu/quickview.do?SERIES KEY=ICP.M.U2.N.000000.4.ANR

ECB, 2011. Výroční zpráva 2011 [online]. [Accessed 27. 9. 2019]. Available at: https://www.ecb.europa.eu/pub/pdf/annrep/ar2011cs.pdf?40ca5eb9e142f3b2da733b017493098f

EUROSTAT, 2021a. Contributions to euro area annual inflation (in percentage points) [online]. [Accessed 8. $3 . \quad 2021]$ Available at: https://ec.europa.eu/eurostat/databrowser/view/PRC HICP CTRB custom 645999/default/tabl e?lang=en

EUROSTAT, 2021b. HICP - inflation rate [online]. [Accessed 8. 3. 2021]. Available at: https://ec.europa.eu/eurostat/tgm/table.do?tab=table\&init=1\&language=en\&pcode=tec00118\&plu gin=1

EUROSTAT, 2021c. Real GDP growth, 2007-2019 (\% change compared with the previous year; \% per annum) [online]. [Accessed 9. 3. 2021]. Available at: https://ec.europa.eu/eurostat/databrowser/view/tec00115/default/table?lang=en 
FREIXAS, Xavier, MARTIN, Antoine, 2009. Bank Liquidity, Interbank Markets, and Monetary Policy [online]. European Banking Center Discussion Paper, no. 8/10. [Accessed 28. 9. 2019]. Available at:

https://poseidon01.ssrn.com/delivery.php?|D=6490171210091070310891251070880160690320 34022058026059113005071074031082099120015112103042027101022023115111116119124 06401102304605106209306007210009208001712512609905904601412706711202002601006 $\underline{9089090091086087126068107072123084015111100019007090122097 \& \mathrm{EXT}=\text { pdf }}$

GREEN, Russell, TORGERSON, Tom, 2007. Are High Foreign Exchange Reserves in Emerging Markets a Blessing or a Burden? [online]. Department of the Treasury: Office of International Affairs, Occasional Paper, no. 6. [Accessed 16.9.2017]. Available at: http://rag8.web.rice.edu/TreasuryOccasionalPaperNo6.pdf

HAUSKEN, Kjell, 2013. Quantitative easing and its impact in the US, Japan, the UK and Europe [online]. New York: SpringerVerlag, p. 78. DOI 10.1007/978-1-4614-9646-5. [Accessed 28. 9. 2019]. Available at: https://www.researchgate.net/publication/314007424 Introduction

HROMADA, E., KRULICKY, T. Investing in Real Estate in the Czech Republic and Analyzing the Dependence of Profitability and Technical and Socio-Economic Factors. Sustainability. 2021; 13(18):10273. https://doi.org/10.3390/su131810273

INVESTOPEDIA, 2019. Subprime Loan Definition [online]. [Accessed 30. 7. 2019]. Available at: https://www.investopedia.com/terms/s/subprimeloan.asp

KADEŘÁBKOVÁ, B., JAŠOVÁ, E. 2020: COMPARATION OF THE ECONOMIC CYCLE ON LABOUR MARKET IN THE CONSTRUCTION INDUSTRY AND IN THE NATIONAL ECONOMY OF THE CZECHIA. Civil Engineering Journal Stavebni obzor,3/2020, DOI 10.14311/CEJ.2020.03.0024

KLIBER, P., RUTKOWSKA-ZIARKO, A. (2021). Portfolio choice with a fundamental criterion - an algorithm and practical applicationon - a computation methods and empirical analysis. International Journal of Economic Sciences, Vol. X(1), pp. 39-52. , DOI: 10.52950/ES.2021.10.1.003

MLČOCHOVÁ, 2012. Řežábek: Fiskální politika zčásti neguje snahu centrální banky [online]. [Accessed 20.7.2017]. Available https://www.cnb.cz/cs/verejnost/pro media/clanky rozhovory/media 2012/cl 12121024 rezabe k reuters.html

NBS, 2017. 2005-2008 (inflačné cielenie v ERM II) [online]. [Accessed 11.12.2017]. Available at: https://www.nbs.sk/sk/menova-politika/menova-politika-nbs-do-roku-2009/2005-2008-inflacnecielenie-v-erm-ii

PARLAMENT ČESKÉ REPUBLIKY, 2008. Smlouva o fungování Evropské unie (ve znění Lisabonské smlouvy) [online]. Parlamentní institut, p. 133. [Accessed 28. 9. 2019]. Available at: https://www.psp.cz/sqw/text/orig2.sqw?idd=20555

SEDLÁČEK, Petr, 2010. Státní investiční fondy - významný institucionální investor globálních finančních trhů [online]. Acta Oeconomica Pragensia, p. 22. [Accessed 28. 9. 2019]. Available at: https://aop.vse.cz/pdfs/aop/2010/02/01.pdf

THE GOVERNING COUNCIL OF THE ECB, 2015. DECISION (EU) 2015/774 OF THE ECB of 4 March 2015 on a secondary markets public sector asset purchase programme (ECB/2015/10) [online]. Official Journal of the European Union, p. 5. [Accessed 28. 9. 2019]. Available at: https://www.ecb.europa.eu/ecb/legal/pdf/oj jol 2015121 r 0007 en txt.pdf

THE GOVERNING COUNCIL OF THE ECB, 2016. DECISION (EU) 2016/702 OF THE ECB of 18 April 2016 amending Decision (EU) 2015/774 on a secondary markets public sector asset purchase programme (ECB/2016/8) [online]. Official Journal of the European Union, p. 3. [Accessed 28. 9. 2019]. Available at: https://www.ecb.europa.eu/ecb/legal/pdf/celex 32016d0008 en txt2.pdf

THE GOVERNING COUNCIL OF THE ECB, 2017. DECISION (EU) 2017/100 OF THE ECB of 11 January 2017 amending Decision (EU) 2015/774 on a secondary markets public sector asset purchase programme (ECB/2017/1) [online]. Official Journal of the European Union, p. 2. $\begin{array}{lllll}\text { [Accessed } 28 . & 9019] & \text { Available }\end{array}$ https://www.ecb.europa.eu/ecb/legal/pdf/celex 32017d0001 en txt.pdf 
TOMAN, Luděk, 2012. Finanční krize a sociální úpadek v Řecku [online]. ČMKOS, no. 3. [Accessed 25. 9. 2019]. Available at: https://www.cmkos.cz/obsah/222/analyza-financni-krize-socialni-upadek-vrecku/12374

TRADING VIEW, 2021. GOLD SPOT / U.S. DOLLAR [online]. [Accessed 8. 3. 2021]. Available at: https://www.tradingview.com/symbols/XAUUSD/

VAUBEL, Roland, 2014. The Breakdown of the Rule of Law in the Euro-Crisis: Implications for the Reform of the Court of Justice of the European Union [online]. Conference on International Law and the Rule of Law under Extreme Conditions, Travemünde Symposium on the Economic Analysis of Law. [Accessed 29. 9. 2019]. Available at: http://minervaextremelaw.haifa.ac.il/images/Vaubel The Breakdown of the Rule of Law in the EU-Crisis 28.04.14.pdf

VLÁDA ČR, 2020. Novela zákona o ČNB umožní lepši koordinaci měnové a fiskální politiky [online]. Ministerstvo financí. [Accessed 8. 3. 2021]. Available at: https://www.vlada.cz/cz/mediacentrum/aktualne/novela-zakona-o-cnb-umozni-lepsi-koordinaci-menove-a-fiskalni-politiky$\underline{180591 /}$

WEIDMANN, Jens, 2016. Challenging times - what lies ahead for the banking sector [online]. Speech delivered at the ceremony marking the centenary of the Association of German Public Sector Banks. Berlin. [Accessed 26. 9. 2019]. Available at: https://www.bundesbank.de/en/press/speeches/challenging-times-what-lies-ahead-for-thebanking-sector-667228

WEIDMANN, Jens, 2018. From extraordinary to normal - reflections on the future monetary policy toolkit [online]. Speech by Dr Jens Weidmann, President of the Deutsche Bundesbank and Chairman of the Board of Directors of the Bank for International Settlements, at the European Banking Congress, Frankfurt am Main. [Accessed 15. 8. 2019]. Available at: https://www.bis.org/review/r181116a.pdf

ZAVADILOVÁ, Tereza, 2014. Každý člen bankovní rady je jinak citlivý [online]. E15, p. 14. [Accessed 14.12.2017]. Available at: https://www.cnb.cz/cs/verejnost/pro media/clanky rozhovory/media 2014/cl $14 \quad 1403$ 04 rezabek e15.html 